\title{
The effect of low solubility organic acids on the hygroscopicity of sodium halide aerosols
}

\author{
L. Miñambres, E. Méndez, M. N. Sánchez, F. Castaño, and F. J. Basterretxea \\ Departamento de Química Física, Facultad de Ciencia y Tecnología, University of the Basque Country, UPV/EHU, \\ Campus de Leioa, B. Sarriena, s/n, Leioa 48940, Spain \\ Correspondence to: L. Miñambres (lorena.minambres@ehu.es)
}

Received: 28 November 2013 - Published in Atmos. Chem. Phys. Discuss.: 18 February 2014

Revised: 13 August 2014 - Accepted: 31 August 2014 - Published: 29 October 2014

\begin{abstract}
In order to accurately assess the influence of fatty acids on the hygroscopic and other physicochemical properties of sea salt aerosols, hexanoic, octanoic or lauric acid together with sodium halide salts $(\mathrm{NaCl}, \mathrm{NaBr}$ and $\mathrm{NaI})$ have been chosen to be investigated in this study. The hygroscopic properties of sodium halide sub-micrometre particles covered with organic acids have been examined by Fourier-transform infrared spectroscopy in an aerosol flow cell. Covered particles were generated by flowing atomized sodium halide particles (either dry or aqueous) through a heated oven containing the gaseous acid. The obtained results indicate that gaseous organic acids easily nucleate onto dry and aqueous sodium halide particles. On the other hand, scanning electron microscopy (SEM) images indicate that lauric acid coating on $\mathrm{NaCl}$ particles makes them to aggregate in small clusters. The hygroscopic behaviour of covered sodium halide particles in deliquescence mode shows different features with the exchange of the halide ion, whereas the organic surfactant has little effect in $\mathrm{NaBr}$ particles, $\mathrm{NaCl}$ and $\mathrm{NaI}$ covered particles experience appreciable shifts in their deliquescence relative humidities, with different trends observed for each of the acids studied. In efflorescence mode, the overall effect of the organic covering is to retard the loss of water in the particles. It has been observed that the presence of gaseous water in heterogeneously nucleated particles tends to displace the cover of hexanoic acid to energetically stabilize the system.
\end{abstract}

\section{Introduction}

Marine aerosol is one of the most abundant types of natural particulate matter in the Earth's troposphere. Sea salt particles play an active role in the Earth's radiative balance, influence mass transfer of gaseous compounds and cloud-precipitation mechanisms, contribute to the formation of cloud condensation nuclei and have highly reactive surfaces that take part in heterogeneous and multiphase chemical reactions (Andreae and Rosenfeld, 2008; Carslaw et al., 2010; O'Dowd and De Leeuw, 2007; Finlayson-Pitts, 2003; Lewis and Schwartz, 2004; Quinn and Bates, 2011; Rossi, 2003). They also can take up significant amounts of water, exhibiting deliquescence and efflorescence properties under atmospheric conditions (Freney et al., 2009; Martin, 2000; Metzger and Lelieveld, 2007; Mikhailov et al., 2013; Wise et al., 2012) that can change the particles' phase and size, together with other interrelated physicochemical properties: for example, water uptake increases particle size, thus favouring their sedimentation. In parallel, bigger particles increase the scattering of solar visible light, thus influencing atmospheric radiative transfer and visibility. The presence of water in atmospheric particles can also change the adsorption of trace gases and their chemical reactivity (e.g. sulfate chemistry proceeds by adsorption of gaseous $\mathrm{SO}_{2}$ on aqueous particles, followed by oxidation to sulfate; this pathway is absent in crystalline particles).

Marine aerosol is generated either by the mechanical action of the ocean surface (primary sea-salt aerosol), or by gas-to-particle conversion processes (secondary aerosol) mainly in the form of non-sea-salt sulfate and organic species (O'Dowd et al., 1997). Sodium chloride is the principal component of sea salt: typical seawater composition has 
$1.05 \times 10^{4} \mathrm{mg} \mathrm{L}^{-1}$ of $\mathrm{Na}^{+}$and $1.9 \times 10^{4} \mathrm{mg} \mathrm{L}^{-1}$ of $\mathrm{Cl}^{-}$ (Lide, 1994). Bromide ions are a minor component of seawater, and hence of sea salt particles, with a molar ratio of bromide to chloride of 1:650 (Lide, 1994). Despite such a small contribution to the composition of sea salt particles, bromine plays a comparatively large role in tropospheric sea salt chemistry. The most important is the drop of surfacelevel ozone concentrations in the Arctic at polar sunrise. This is due to the tendency of $\mathrm{Br}^{-}$to segregate to the salt surface in the presence of water, substantially increasing $\mathrm{Br} / \mathrm{Cl}$ surface molar ratios, and to the fact that bromide ions exhibit a higher surface reactivity than chloride (Baker, 2005; Ghosal et al., 2008; Zangmeister et al., 2001). Sea salt particles have been shown to be the source of $\mathrm{BrO}$, which is involved in catalytic cycles that destroy ozone (FinlaysonPitts, 2009; Frinak and Abbatt, 2006; Hunt et al., 2004; Read et al., 2008; Von Glasow, 2008). Although the concentrations of $\mathrm{I}^{-}$present in seawater are much smaller than those of bromine and chlorine (the molar ratio of $\mathrm{I}^{-}$to $\mathrm{Cl}^{-}$in seawater is $\sim 1: 10^{6}$ ), there is evidence that iodine in the marine boundary layer has an influence on ozone destruction, the oxidizing capacity of the troposphere, de-noxification, and particle formation (Carpenter, 2003; Saiz-Lopez et al., 2008). A similar role to $\mathrm{BrO}$ (bromine oxide free radical) is played by IO (iodine oxide free radical), although its source is believed to come from marine algae (Read et al., 2008). Recently advances have been made in quantifying the link between seawater chemical processes, and the production, size, and chemical composition of sea-spray aerosol particles by simultaneous measurements of seawater, particle size distributions, and size-resolved single particle chemical composition in a laboratory setting reproducing the chemical complexity of sea-spray aerosol, including natural seawater, breaking waves and controlled phytoplankton and heterotrophic bacteria concentrations (Ault et al., 2013; Prather et al., 2013). It has been shown that the mixing state of sea aerosol is sensitive to the presence of heterotrophic bacteria that transform dissolved organic matter.

Organic compounds are present in marine salt aerosol in variable proportions that may represent a large fraction of the aerosol dry mass (Cavalli et al., 2004; Gantt and Meskhidze, 2013; Middlebrook et al., 1998). The presence of significant concentrations of organic matter in marine aerosol was detected in earlier studies (Kleefeld et al., 2002; Middlebrook et al., 1998; Putaud et al., 2000). Measures over the North Atlantic Ocean have revealed that the organic fraction contributes up to $63 \%$ to the sub-micrometre aerosol mass, of which about $45 \%$ is water-insoluble and $18 \%$ water-soluble (O'Dowd et al., 2004). $37 \%$ hydrocarbon and $63 \%$ oxygenated hydrocarbon speciation was observed for the organic mass indicating that at least $37 \%$ of the organic mass is produced via primary sea-spray (Ovadnevaite et al., 2011a). It was found that predominantly organic particles contribute between 25 and $30 \%$ to general background marine number concentration, $35 \%$ for open ocean nucleation cases, and $60 \%$ for anthropogenically influenced cases (Bialek et al., 2012). The organic fraction of marine aerosol can be highly enriched due to oceanic biological activity (Ault et al., 2013; Gantt and Meskhidze, 2013; O’Dowd et al., 2002; Ovadnevaite et al., 2011a; Rinaldi et al., 2010). Much of the organic fraction corresponds to water insoluble fatty acids present as surface films on particles (Donaldson and Vaida, 2006; Mochida et al., 2002; Tervahattu et al., 2002), but also as organic carbon more homogeneously mixed with cations and anions (Ault et al., 2013).

Moreover, fine-mode marine organic aerosol can have a size distribution independent from that of sea-salt, while coarse mode aerosols are more likely to be internally mixed with sea-salt (Gantt and Meskhidze, 2013). Primary marine aerosols mixed with a surfactant can be generated by wind action on the sea surface, which is covered by a low solubility organic layer (Donaldson and Vaida, 2006). Alternatively, heterogeneously nucleated particles can form when low vapour pressure organic vapours condense on preexisting aerosol particles, forming a surface coating, which can be evenly or unevenly distributed. It has been proposed that the organic compounds arrange in a hydrophobic organic monolayer that encapsulates an aqueous particle, forming an "inverted micelle" structure (Ellison et al., 1999). This model shows agreement with recent molecular dynamic simulation results (Chakraborty and Zachariah, 2008). Other models predict that certain fatty acids form pockets of micelles within the aerosol, modifying the surface tension of the particle and therefore changing the water uptake properties of atmospheric aerosols (Tabazadeh, 2005), and that core-shell structures are not always the most stable (Kwamena et al., 2010), again affecting the particle water uptake properties and optical properties.

The presence of an organic film at the surface of a particle may affect its physical and chemical properties in a number of ways. The film may act as a barrier to transport across the interface, inhibiting uptake of atmospheric gases or reactions between gas phase reactants and particle surface, such as the heterogeneous reaction $\mathrm{NaCl}(\mathrm{s})+2 \mathrm{NO}_{2}(\mathrm{~g}) \rightarrow \mathrm{ClNO}(\mathrm{g})$ $+\mathrm{NaNO}_{3}$ (s) (Donaldson and Vaida, 2006; Finlayson-Pitts, 2003). In particular, the surface film can affect the process of cloud condensation nuclei formation and aerosol growth to climatically relevant sizes (Andrews and Larson, 1993; Chuang, 2003). Organic compounds can also change the amount of light scattered by inorganic particles (Dall'Osto et al., 2010; Fierz-Schmidhauser et al., 2010; Vaishya et al., 2013). Marine primary organic aerosol (POA) can cause large local increases in the cloud condensation nuclei concentration by $15 \%$ to more than $100 \%$ (O'Dowd et al., 2004; Ovadnevaite et al., 2011b), and the ambient mass concentration and organic mass fraction of sea-spray aerosol are related to surface ocean biological activity. Despite the considerable work that has been carried out in recent years, there is still much uncertainty about the fundamental properties of marine aerosol particles, such as chemical composition, 
mixing state, hygroscopicity, cloud droplet activation, formation, aging, and removal mechanisms (Gantt and Meskhidze, 2013; IPCC, 2013). Several laboratory studies about the effect of organic surfactants, such as palmitic and oleic acids, on $\mathrm{NaCl}$, ammonium sulfate or mineral dust aerosol particles as a function of relative humidity have been reported employing a variety of experimental techniques, such as electrodynamic balance, infrared spectroscopy, electrical mobility, optical tweezers, cavity ring-down spectroscopy or nonlinear spectroscopy (Cwiertny et al., 2008; Davies et al., 2013; Dennis-Smither et al., 2012; Ebben et al., 2013; Garland et al., 2005; Hansson et al., 1998; Najera and Horn, 2009; Robinson et al., 2013; Rossi, 2003; Rubasinghege et al., 2013). The general conclusions are that hygroscopic growth, deliquescence relative humidity (DRH) and efflorescence of the particles at efflorescence relative humidity (ERH) may be affected by several factors, such as coating thickness or structural arrangement of the organic film. Special effort has been carried out to study the morphology and phase partitioning of aerosol particles consisting of hydrophobic and hydrophilic phases (Ciobanu et al., 2009; Kwamena et al., 2010; Reid et al., 2011; Veghte et al., 2013). On the other hand, molecular dynamics calculations are becoming a commonplace theoretical approach in atmospheric aerosol modelling that includes sea salt particles mixed with organic molecules (Ma et al., 2011; Sun et al., 2012, 2013; Takahama and Russell, 2011).

As a whole, laboratory studies on inorganic particles coated with surfactant organics have mainly focused on a few organic molecules, and most of them have been carried out with ammonium sulfate or sodium chloride. Very few studies of hygroscopic behaviour have been carried out on particles containing bromide or iodide. Furthermore, sodium chloride, bromide and iodide particles exhibit very different hygroscopic properties and interact differently with water soluble dicarboxylic acids such as succinic acid (Minambres et al., 2011). It has been reported that rates of gaseous iodine emissions during the heterogeneous reaction of $\mathrm{O}_{3}$ with interfacial iodide are enhanced several-fold by the presence of alkanoic acids on water, such as octanoic and hexanoic acid (Hayase et al., 2011). In the present work we study the hygroscopic properties of $\mathrm{NaX}(\mathrm{X}=\mathrm{Cl}, \mathrm{Br}, \mathrm{I})$ sodium halide salts coated with either one of three different surfactant carboxylic acid molecules by Fourier-transform infrared extinction spectroscopy in an aerosol flow tube, aided by particle sizing methods. The examined acids, all contain one carboxylic group at the end of the molecule, are hexanoic $\left(\mathrm{CH}_{3}\left(\mathrm{CH}_{2}\right)_{4} \mathrm{COOH}\right)$, octanoic $\left(\mathrm{CH}_{3}\left(\mathrm{CH}_{2}\right)_{6} \mathrm{COOH}\right)$ and dodecanoic or lauric acid $\left(\mathrm{CH}_{3}\left(\mathrm{CH}_{2}\right)_{10} \mathrm{COOH}\right)$, hereafter shortened as HA, OA and LA, respectively. These acids belong to the family of alkanoic acids that make a significant proportion of the organic compounds emitted from several sources to the atmosphere, such as seed oil and meat cooking procedures or emission by plants. The substances emitted in coastal areas can condense onto preexisting marine aerosol and modify their properties. HA, OA and LA have been observed in the atmosphere of remote marine and continental locations (Duce et al., 1983; Gill et al., 1983; Limbeck and Puxbaum, 1999; Samy et al., 2010; Schauer et al., 1999, 2002; Yassaa et al., 2001). OA and LA exist as liquid and solid, respectively, at typical tropospheric temperatures and pressures. HA has higher vapour pressure than the atmospherically more abundant long chain acids that may contribute more substantially to vapour phase processes. HA, OA and LA have water solubilities of 9.9, 0.68 and $0.058 \mathrm{~g} \mathrm{~L}^{-1}$ at $20^{\circ} \mathrm{C}$, respectively (see Table 1), and have been selected as they are expected to influence the hygroscopic behaviour of sea-salt particles differently in view of their water solubilities: HA has intermediate solubility between highly soluble and highly insoluble organic acids, whereas LA, on the other end, can represent highly insoluble fatty acids, OA lying in-between. Due to their overall low water solubility, pure fatty acids are not expected to present significant intrinsic hygroscopic properties.

A few studies have been presented describing the effects of octanoic and lauric acids on the hygroscopicity of $\mathrm{NaCl}$ (Hämeri et al., 1992; Hansson et al., 1998; Wagner et al., 1996). The results indicate that formation of organic surfactant layers tend to slow $\mathrm{NaCl}$ deliquescence rate and to slightly lower its DRH. This may affect particle size and phase, changing the amount of scattered solar radiation and also the adsorption behaviour of trace gases onto particles. Molecular dynamics simulations of water vapour molecules impinging on a slab of water coated by octanoic acid film showed that the mass accommodation coefficient decreased with the degree of surface coverage of the hydrocarbon backbones (Takahama and Russell, 2011).

\section{Materials and methods}

Infrared spectroscopy is a well-known sensitive technique and has been applied to the study of organic/inorganic aerosol systems (Garland et al., 2005; Najera and Horn, 2009). It can yield aerosol composition, water content, and particle phase. Variations in the wave numbers and widths of spectral bands (precisely their FWHM: full width at half maximum) can also reveal information about molecular interactions in mixed systems and the formation of new species. Infrared spectra have been combined with electron scanning microscopy (SEM) of particles, a technique that has been demonstrated to be useful to study the chemistry of isolated, individual particles of atmospheric relevance (Krueger et al., 2003; Veghte et al., 2013).

The configuration of the experimental setup used in this work is based on a previously described system (Minambres et al., 2010) that has been modified for the present study. The main elements are depicted in Fig. 1. Sub-micrometric particles are formed by injecting a $0.01 \mathrm{~kg} \mathrm{~L}^{-1}$ aqueous solution of sodium halide salts $(\mathrm{NaCl}, \mathrm{NaBr}$ and $\mathrm{NaI}, \geq 98 \%)$ in a commercial atomizer (TSI 3076). Their relative humidity 
Table 1. Physical properties of the studied carboxylic acids.

\begin{tabular}{|c|c|c|c|c|c|c|}
\hline Name & $\# \mathrm{C}$ & Structural Formula & $\begin{array}{r}\text { Melting } \\
\text { Point }(\mathrm{K})^{\mathrm{a}}\end{array}$ & $\begin{array}{r}\text { Boiling } \\
\text { Point }(\mathrm{K})^{\mathrm{a}}\end{array}$ & $\begin{array}{l}\text { Water solubilities } \\
\left(20^{\circ} \mathrm{C}, \mathrm{g} \mathrm{L}^{-1}\right)^{\mathrm{b}}\end{array}$ & $\begin{array}{l}\text { Vapour pressure } \\
\left(\text { mbar, } 25^{\circ} \mathrm{C}\right)^{\mathrm{c}}\end{array}$ \\
\hline Hexanoic Acid & 6 & $\mathrm{Ol}$ & 269.7 & $477 \pm 4$ & 9.9 & 0.272 \\
\hline Octanoic Acid & 8 & O & $289.3 \pm 0.7$ & $510 \pm 4$ & 0.68 & $5.05 \times 10^{-3}$ \\
\hline Lauric Acid & 12 & & $317 \pm 2$ & 571 & 0.058 & $2.18 \times 10^{-5}$ \\
\hline
\end{tabular}

(RH) can be controlled (from 0 to around $95 \%$ ) by combining two serially connected diffusion driers and a flow of $\mathrm{N}_{2}$ with a controlled amount of water vapour. RH is measured with a digital thermo-hygrometer (Vaisala Humicap HMT 337) placed at the exit of the aerosol flow cell (see Fig. 1). The measurement error is $1 \% \mathrm{RH}$ in the $0-90 \% \mathrm{RH}$ range, and $1.7 \%$ outside it. Hygrometer absolute $\mathrm{RH}$ values were periodically checked against a calibration curve obtained by recording the integrated infrared absorption of water vapour (measured from 2166 to $1188 \mathrm{~cm}^{-1}$ in the $\mathrm{H}_{2} \mathrm{O}$ bending $\nu_{2}$ fundamental band) flowing through the aerosol cell at selected RH values (measured with the hygrometer). Measurements are carried out after the RH of the aerosol flow reaches a constant value with fluctuations within the RH measurement error. The inorganic particles are coated by passing the aerosol flow $\left(1.8 \mathrm{~L} \mathrm{~min}^{-1}\right)$ through a heated cell that contains a sample of either hexanoic $(99 \%)$, octanoic $(\geq 98 \%)$, or lauric acid $(\geq 98 \%)$. Table 1 summarizes the most relevant physical properties of these acids.

The heating cell consists of an horizontally set cylindrical borosilicate glass tube $30 \mathrm{~cm}$ long having $3 \mathrm{~cm}$ internal diameter, that has two smaller glass tubes $(30$ and $20 \mathrm{~cm}$ long, $1 \mathrm{~cm}$ internal diameter) coaxially attached at its ends. Acid sample (either liquid or solid) is placed uniformly along the central tube. The whole cell is thermally isolated by wrapping it with alumino-silicate refractory ceramic fiber. To allow for sufficient vaporization of the acid, the central tube and exit arm of the cell are heated up to $100^{\circ} \mathrm{C}$ by means of flexible resistors coiled around them. The temperatures at both cell locations ( $T_{1}$ refers to the central part, $T_{2}$ to the exit arm, see Fig. 1) are controlled by placing two K-type thermocouples at the cell outer walls. To form heterogeneously nucleated particles, $T_{1}$ was varied from 75 to $100^{\circ} \mathrm{C}$ and $T_{2}$ from 60 to $90^{\circ} \mathrm{C}$. Higher temperature indicates higher concentration in the gas phase leading to enhanced condensation and larger particles and therefore thicker coating. The temperature measurement errors are estimated to be in the

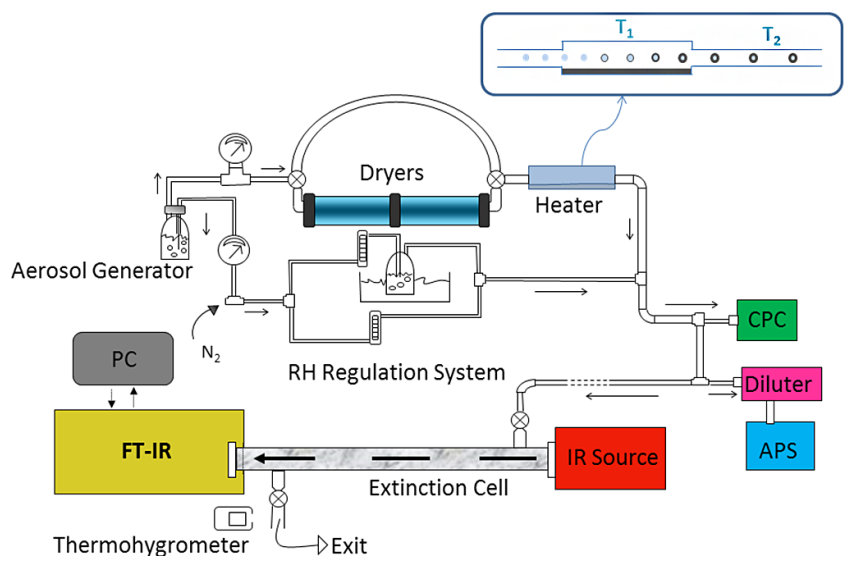

Figure 1. A diagram of the experimental setup. $\mathrm{RH}$ is measured by a thermo-hygrometer with the sensor placed at the exit of the aerosol flow cell. The heating cell where the organic acid sample is located can be heated by two independent resistors at two different temperatures: $T_{1}\left(75-100^{\circ} \mathrm{C}\right)$ in the central part of the tube and $T_{2}$ $\left(60-90^{\circ} \mathrm{C}\right)$ at the exit arm.

$4-7{ }^{\circ} \mathrm{C}$ range (the higher value corresponds to the highest temperature). A prominent baseline shift was observed in all cases, in agreement with particle formation. This shift increases with $T_{1}$ and $T_{2}$, indicating bigger particles. Purely homogeneously nucleated particles were formed by passing a flow of gaseous nitrogen through the heated oven at $T_{1}=80-100^{\circ} \mathrm{C}$ and $T_{2}=60-90^{\circ} \mathrm{C}$ containing the carboxylic acid. This coating method can get a reproducible amount of fatty acid on particles in a fast and convenient way, and has been used by other authors in laboratory experiments (Abbatt et al., 2005; Garland et al., 2008; Rouvière and Ammann 2010; Stemmler et al., 2008). Although in the troposphere the whole process of heterogeneous nucleation of organic vapours takes place at overall lower temperatures, in our experiment the heated organic vapour gets in contact with the nitrogen gas flow at ambient temperature that effectively 
cools the vapour by rapid heat exchange (the number density of nitrogen molecules in the gas flow is much higher than the number density of organic vapour molecules in the tube). Eventually, cooled gas-phase organic molecules heterogeneously nucleate on salt particles in the nitrogen gas flow. In that way, the way to generate heterogeneously nucleated particles can be assumed to follow the same physical process than in the atmosphere, although the temperatures can vary over a broad range.

The final aerosol flux was directed simultaneously to a condensation particle counter (CPC, either TSI 3781 or MSP 1040XP models, inlet flow $0.6 \mathrm{~L} \mathrm{~min}^{-1}$ ), an aerodynamic particle spectrometer (APS,TSI 3321, inlet flow 1.0 $\mathrm{L} \mathrm{min}^{-1}$ ) and a Fourier-transform infrared spectrometer (Nicolet Magna 860), to obtain particle number, size distribution and their infrared extinction spectra, respectively. Infrared extinction spectra are recorded in the $650-4000 \mathrm{~cm}^{-1}$ range and $4 \mathrm{~cm}^{-1}$ resolution. Infrared radiation from a collimated source (ORIEL 6580) travels lengthways a $1 \mathrm{~m} \mathrm{long,}$ $50 \mathrm{~mm}$ diameter Pyrex absorption cell at ambient temperature with zinc selenide windows. The outgoing radiation is directed to the infrared spectrometer (Fig. 1), where the infrared beam is divided into two. Both beams take slightly different path lengths, and recombine to construct an interferogram. The recombined intensity is recorded as the path length difference is changed. By applying the Fourier transform technique, the variation of the intensity with the wave number is retrieved. The optical path is sealed and flushed by a current of dry air to reduce interference from ambient water and carbon dioxide. Background spectra are recorded after pumping out the aerosol cell. Sample spectra are averaged by collecting typically 32 scans. To complete analytical on-line methodology, particle shape and size of both pure and mixed particles were determined off-line using a JEOL JSM-7000F scanning electron microscope (SEM), equipped with a Schottky field emission gun (FEG) and an Oxford Inca Pentafet X3 energy dispersive X-ray analyzer (EDX). The EDX microanalysis was performed using an accelerating voltage of $20 \mathrm{kV}$ and a current density of $10^{-10} \mathrm{~A}$ with a working distance of $10 \mathrm{~mm}$. The aerosol of interest was collected at the exit of the extinction flow cell onto a glass slide, and particles were coated with an Au layer $(20 \mathrm{~nm})$ deposited by evaporation using a Quorum Q150T Sputter Coater to provide electrical conductivity.

Particle size distribution in the $0.5-20 \mu \mathrm{m}$ is retrieved by an aerodynamic particle spectrometer (TSI 3321), that give a tail in the $0.5-3.5 \mu \mathrm{m}$ range. Information about the size distribution of pure salt particles in the $0-0.5 \mu \mathrm{m}$ range was obtained by processing the SEM images with the help of the ImageJ software [http://rsbweb.nih.gov/ij/docs/intro.html]. The obtained distribution fitted satisfactorily to a lognormal distribution with a count median diameter of $46 \mathrm{~nm}$ and $\sigma=2.0$. Particles appear mostly isolated without a tendency to aggregate. Representative examples of number size distributions of pure $\mathrm{NaCl}$ particles and also covered with hexanoic acid are presented in Fig. 2.

The amounts of liquid-water and a given organic acid in the particles can be calculated on average from measured absorbances in their infrared spectra. The number of molecules $N_{i}$ of a given species $i$ per unit volume of aerosol sample is related with the integrated band absorbance of that species via the Beer-Lambert law (Weis and Ewing, 1996): $\bar{A}_{i}=$ $\bar{\sigma}_{i} N_{i} z / 2.303 \times 10^{2}$, where $\bar{A}_{i}$ is the integrated absorbance of a given band $\left(\mathrm{cm}^{-1}\right), \bar{\sigma}_{i}$ the integrated absorption cross section per molecule (m molecule ${ }^{-1}$ ) of that band, and $z$ is the optical path length of the aerosol flow cell (m). The $\bar{\sigma}_{i}$ value can be taken from the literature or measured independently. The concentration of $\mathrm{Na}^{+}$and $\mathrm{X}^{-}$ions cannot be quantified by this method, as monoatomic ions do not present vibrational spectra.

\section{Results and discussion}

\subsection{Infrared spectra of pure carboxylic acids}

The infrared absorption spectra of bulk HA, OA and LA recorded at ambient temperature are presented in Fig. 3. The spectra of HA and OA were recorded in an infrared cell for liquids, whereas for LA one drop of the sample dissolved in ethanol was deposited on a $\mathrm{BaF}_{2}$ window until solvent evaporation, after which the absorption spectrum of the film was recorded. The main absorption bands are common to all three acids, with small differences in band position and intensity.

The sharp carbonyl stretching band can be seen near $1710 \mathrm{~cm}^{-1}$, the broad band in the $2500-3500 \mathrm{~cm}^{-1}$ range has been assigned to associated COO-H stretchings (broadened by intermolecular association by hydrogen bonding), whereas the group of three peaks in the $2800-3000 \mathrm{~cm}^{-1}$ range, exhibiting a different resolvable structure for the different acids, has been assigned to $-\mathrm{C}-\mathrm{H}$ stretchings. A more complex band system appears in the $800-1500 \mathrm{~cm}^{-1}$, specific of each acid. On the other hand, the gas phase infrared spectra of the three acids (NIST Chemistry Webbook: http: //webbook.nist.gov/chemistry, not shown in Fig. 3) show several differences with the bulk phase spectrum: the intense $\mathrm{C}=\mathrm{O}$ band locates in the $1780-1790 \mathrm{~cm}^{-1}$, whereas a narrow band appears near $3580 \mathrm{~cm}^{-1}$ (COO-H free stretch), absent in the condensed phase. Overlapped bands appearing in the $2800-3000 \mathrm{~cm}^{-1}$ range are coincident with peak positions in bulk phase spectra. Finally, a number of bands are present in the $800-1600 \mathrm{~cm}^{-1}$ region, several of which can be distinguished from condensed phase spectra.

Figure 3 also shows the extinction spectra of pure, homogeneously nucleated particles. Bands belonging to each acid were detected in all cases, their absorption intensity growing with increasing $T_{1}$ and $T_{2}$. CPC measurements confirmed the presence of particles that were assumed to be composed of pure carboxylic acids. For HA the obtained spectra is mostly 


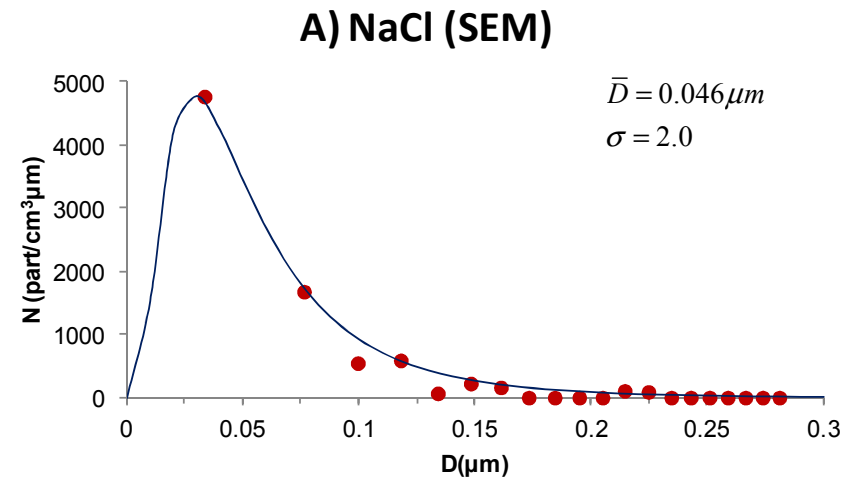

B) $\mathrm{NaCl}$ (APS)

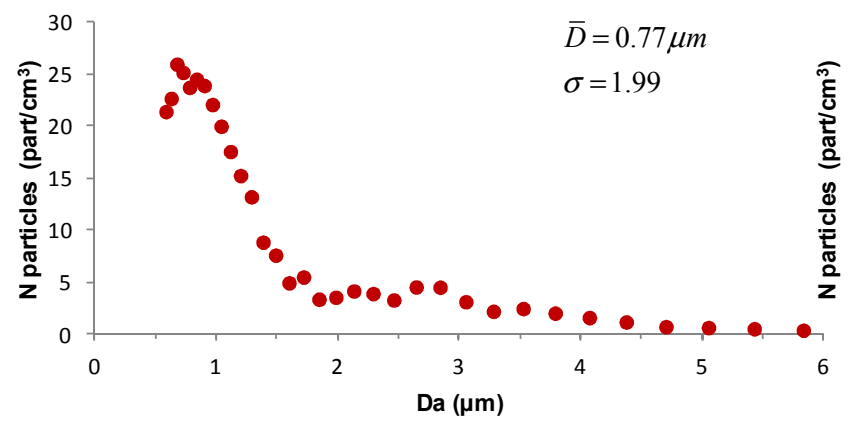

C) $\mathrm{NaCl}+\mathrm{Hexanoic} \mathrm{Acid(APS)}$

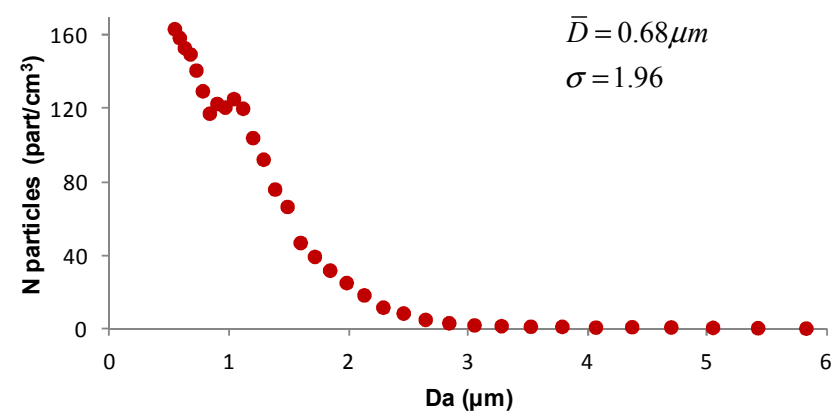

Figure 2. Representative particle size distributions of dry $\mathrm{NaCl}$ aerosol. Panel (a) has been obtained by imaging particles deposited on a glass slide by SEM technique and counting them with the ImageJ software [http://rsbweb.nih.gov/ij/docs/intro.html]. Panels (b) and (c) have been obtained by sizing particles by an aerodynamic particle spectrometer; pure $\mathrm{NaCl}$ particles (b) and heterogeneously nucleated particles with hexanoic particles (c) are shown.

coincident with the gas phase spectrum. A weak band located at near $1730 \mathrm{~cm}^{-1}$ has been assigned to the $\mathrm{C}=\mathrm{O}$ stretch originating from small particles of liquid HA due to homogeneous nucleation. This band is $21 \mathrm{~cm}^{-1}$ displaced to higher wave numbers with respect to bulk liquid HA, possibly due to surface effects in small particles: due to the interactions between surface molecules and the surrounding medium, the surface region has different structural properties (and thus

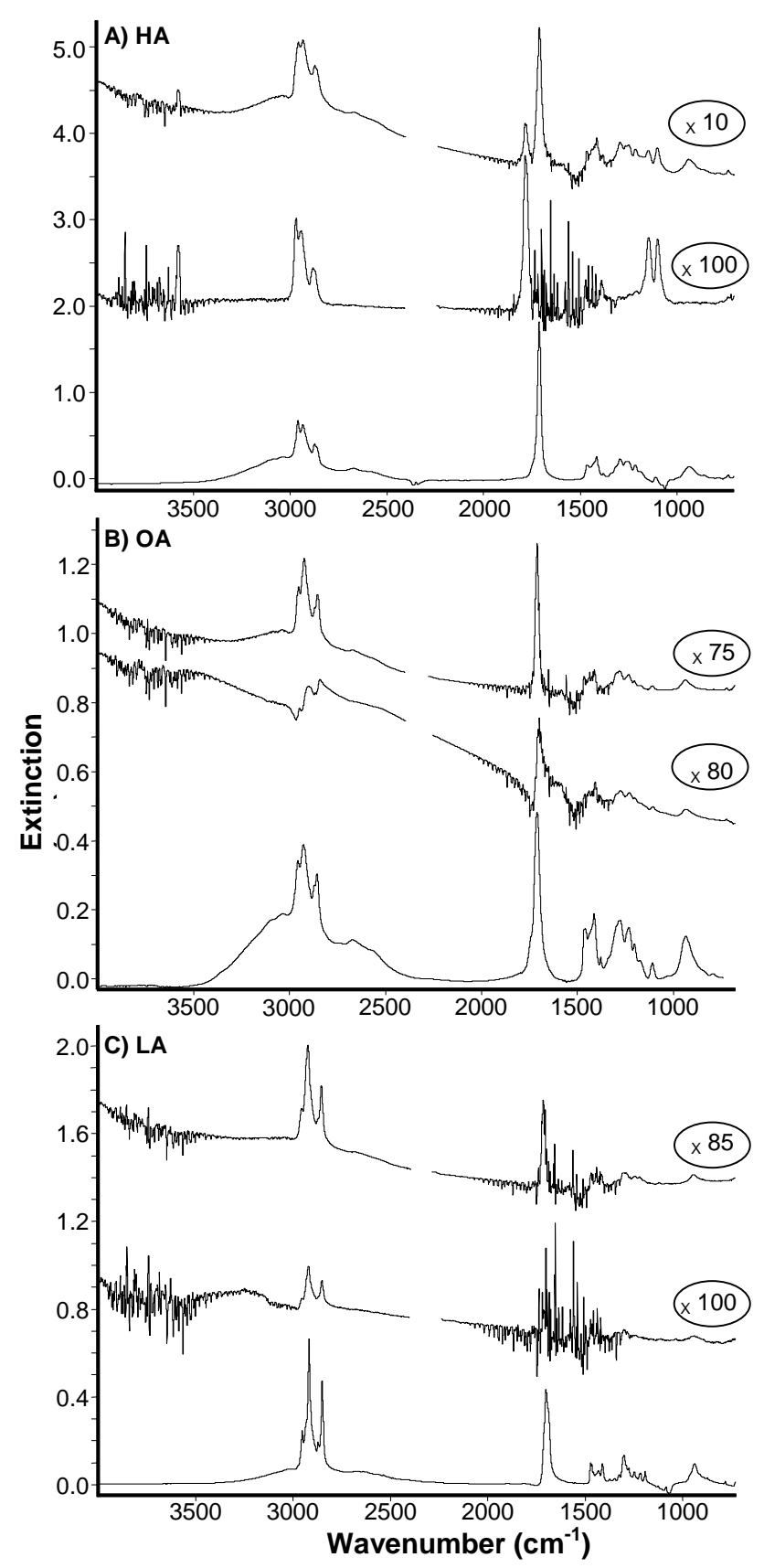

Figure 3. Infrared extinction spectra of HA (a), OA (b) and LA (c) in different conditions: bottom spectra are from bulk phase acid; medium spectra corresponds to homogeneously nucleated acid particles; upper spectra are from heterogeneously nucleated acids onto $\mathrm{NaCl}$ particles. In all cases, the upper spectra have been increased for clarity (increasing factor: $\times$ Number).

spectroscopic features) than the core of the particles (Firanescu et al., 2006). This hypothesis is supported by the spectrum of liquid HA adsorbed at the air/water interface by vibrational sum-frequency spectroscopy (Soule et al., 2007), that locates the $\mathrm{C}=\mathrm{O}$ band in the $1726-1730 \mathrm{~cm}^{-1}$ range, 
depending on the polarization conditions. For $\mathrm{OA}$, the $\mathrm{C}=\mathrm{O}$ band was peaked at near $1700 \mathrm{~cm}^{-1}$, but broader than the one corresponding to condensed phase. Also an overlapping band system in the $1540-1650 \mathrm{~cm}^{-1}$ range was observed. No lines of gaseous OA were detected. For LA, no gas band features were present, in accordance with its low vapour pressure. Further evidence of the presence of particles is given by the baseline increase to higher wave numbers (Fig. 3), which is indicative of particle scattering (Hinds, 1998). This effect is more pronounced as $T_{2}$ is increased. A broad band in the $3100-3500 \mathrm{~cm}^{-1}$ range is observed for homogeneously nucleated hexanoic and octanoic acid that is absent in the bulk spectrum. This feature may arise from the presence of small amounts of liquid-water outgassed from the acid that become trapped into the particles (Safar et al., 1994).

The most notable differences in band wave number and bandwidth for the three acids are observed for the $\mathrm{C}=\mathrm{O}$ stretching band, and are summarized in Table 2. These differences can be significant, as they can be related to surface effects that can give information about the particles. Carbonyl bandwidth in the bulk acids is in the $20-29 \mathrm{~cm}^{-1}$ range, and increases with molecular mass. These values change in homogeneously nucleated organic particles, either increasing (HA and OA) or decreasing (LA). Relative variations in its magnitude are in the $25-75 \%$ range.

\subsection{Infrared extinction spectra of heterogeneously nucleated $\mathrm{NaX}$ particles with carboxylic acids}

Representative infrared extinction spectra of heterogeneously nucleated sodium halide particles are shown in Fig. 3. The band intensities of heterogeneous nucleation spectra are much higher than those of homogeneous nucleation (e.g. $4: 1$ for $\mathrm{NaCl} / \mathrm{OA}$ at $T_{1}=90^{\circ} \mathrm{C}, T_{2}=80^{\circ} \mathrm{C}$ ). For $\mathrm{NaX} / \mathrm{HA}$ particles, bands caused both by gaseous and condensed phase HA were observed. The latter increase in intensity with $T_{1}$ and $T_{2}$, whereas the former remain constant. For $\mathrm{NaX}$ covered with OA or LA, practically all infrared bands originate from condensed phase, gas phase OA bands being very weak or absent. The observed carbonyl absorption band wave number and bandwidth for the various acids are collected in Table 2. The changes in these magnitudes with respect to their bulk phase values are indicative of organic molecule/inorganic ion interactions, and can be used to address the effect of the ionic salt environment near the organic acid molecules. For all acids the $\mathrm{C}=\mathrm{O}$ stretch wave number of the acid coating on $\mathrm{NaX}$ varies with the salt and is between the wave number of the corresponding bulk acid and that of the homogeneously nucleated acid particles (Table 2). In all cases, bulk wave number of $\mathrm{C}=\mathrm{O}$ is around $70 \mathrm{~cm}^{-1}$ lower than in the gas phase, bulk LA showing the lowest wave number $\left(1700 \mathrm{~cm}^{-1}\right)$. On the other hand, the bandwidths of the $\mathrm{C}=\mathrm{O}$ stretch originating from heterogeneously nucleated particles depend on the nature of the salt, the organic acid and the degree of covering: for HA-covered particles, the full width half-maximum (FWHM) can reach $40 \mathrm{~cm}^{-1}$, doubling the bulk HA value, whereas for LA-coated particles it is smaller than the bulk acid bandwidth. The relationship of these results with the hygroscopic properties will be discussed later.

\subsection{Morphology of pure and mixed particles}

SEM images of pure $\mathrm{NaCl}$ and LA particles, and of $\mathrm{NaCl}$ particles after covering them with LA, were recorded and are presented in Fig. 4. This technique was not well suited to study particles that included OA or HA due to their high vapour pressure at room temperature that hinders their manipulation in the SEM vacuum chamber. Images of pure $\mathrm{NaCl}$ particles show particles of cubic form as expected but with their edges somewhat rounded, as a result of a short exposure of deposited particles to ambient air before being coated with the gold layer. $\mathrm{As} \mathrm{NaCl}$ is very hygroscopic, the particles have taken up a small amount of gaseous water enough to change their original morphology (see Fig. 4a).

Images of LA particles (Fig. 4b) show a much smaller number of particles that tend to form big aggregates, typically of $1-2 \mu \mathrm{m}$ length. This is in accordance with previous studies (Gadermann et al., 2008). The particles are amorphous and elongated. Images of $\mathrm{NaCl}$ particles deposited jointly with LA (after heterogeneous nucleation, see Fig. 4c) show a small number of particles, much fewer than in the case of pure $\mathrm{NaCl}$, although the initial amount of $\mathrm{NaCl}$ aerosol was identical in both cases (this may be due to the low affinity of the mixture with the supporting material or to higher tube losses). Most particles present cubic form, and tend to appear as aggregates. Although pure LA particles can be observed, they are very scarce. A thin layer covering the $\mathrm{NaCl}$ particles can be observed, smaller $\mathrm{NaCl}$ particles appearing usually immersed in a surfactant drop. Thus it can be said that a thin layer of lauric acid is deposited on $\mathrm{NaCl}$ particles, acting as glue that tends to link individual $\mathrm{NaCl}$ particles.

\subsection{Deliquescence and efflorescence of heterogeneously nucleated NaX particles with HA, OA and LA}

\subsubsection{Infrared spectra of particles at various RHs}

To examine the deliquescence behaviour, dry $\mathrm{NaX}$ particles coated with each of the carboxylic acids were mixed with a flow of gaseous water at different RHs. As a representative example, Fig. 5 shows three spectra of $\mathrm{NaBr}$ particles covered with OA at various RHs. The presence of liquid water can be detected and quantified by the broad band centered at near $3400 \mathrm{~cm}^{-1}$. For all cases, no infrared absorption bands arising from aqueous dissolved acids were detected, so in all the subsequent discussion all the organic acids are assumed to be undissolved in liquid water. 
Table 2. Wave numbers of the $\mathrm{C}=\mathrm{O}$ stretching band in various conditions for HA, OA and LA. Units in $\mathrm{cm}^{-1}$.

\begin{tabular}{|c|c|c|c|c|c|c|}
\hline & \multicolumn{2}{|c|}{ Hexanoic acid (HA) } & \multicolumn{2}{|c|}{ Octanoic acid (OA) } & \multicolumn{2}{|c|}{ Lauric acid (LA) } \\
\hline & $\begin{array}{l}\text { band } \\
\text { maximum }\end{array}$ & FWHM & $\begin{array}{l}\text { band } \\
\text { maximum }\end{array}$ & FWHM & $\begin{array}{l}\text { band } \\
\text { maximum }\end{array}$ & FWHM \\
\hline $\operatorname{gas}^{\mathrm{a}}$ & 1780 & 26 & 1780 & 62 & 1790 & 30 \\
\hline bulk & 1710 & 20 & 1713 & 26 & 1700 & 29 \\
\hline homog. nucl. & 1730 & 26 & 1700 & 46 & 1710 & 21 \\
\hline heter. $\mathrm{NaCl}^{\mathrm{b}}$ & 1717 & $27-40^{\mathrm{c}}$ & 1707 & 19 & 1710 & 19 \\
\hline heter. $\mathrm{NaBr}^{\mathrm{b}}$ & $1711-1720^{\mathrm{c}}$ & $27-37^{\mathrm{c}}$ & 1713 & 23 & 1708 & 26 \\
\hline heter. $\mathrm{NaI}^{\mathrm{b}}$ & 1720 & 33 & 1713 & 36 & 1707 & 13 \\
\hline
\end{tabular}

a NIST Chemistry Webbook: http://webbook.nist.gov/chemistry.

b Dry particles.

c Depending on the amount of acid deposited onto the salt particles.
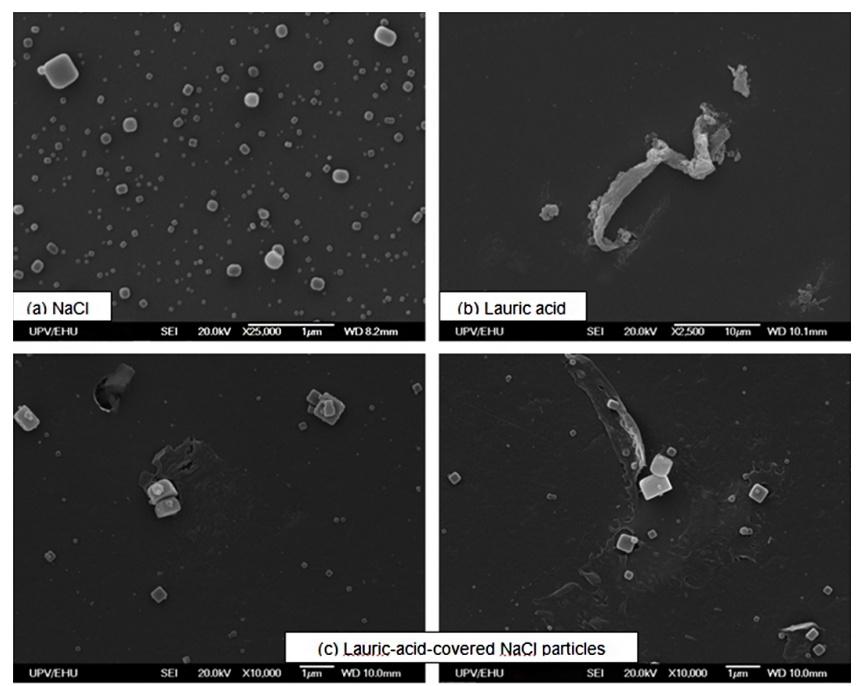

Figure 4. SEM images of: (a) pure $\mathrm{NaCl}$ particles; (b) pure LA particles; (c) $\mathrm{NaCl}$ particles covered with LA.

In all cases, we paid special attention to the $\mathrm{C}=\mathrm{O}$ stretching band of the acids near $1700 \mathrm{~cm}^{-1}$, and we analyzed it as a function of RH, organic acid, and halide anion measured. In $\mathrm{OA} / \mathrm{NaX}$ and LA / NaX particles the carbonyl band absorption intensity of condensed phase acid keeps constant with RH. For NaX/HA particles, on the contrary, the band intensities of liquid HA decrease as RH increases, although the intensities of gaseous HA remain unchanged. As an example, the spectra in Fig. 6 show the intensity variation of the carbonyl band near $1700 \mathrm{~cm}^{-1}$ as $\mathrm{RH}$ is varied for liquid and gaseous $\mathrm{HA}$ in $\mathrm{NaBr}$ particles in deliquescence and efflorescence modes. It can be seen that, while the $\mathrm{C}=\mathrm{O}$ band intensity of gaseous HA keeps roughly constant with RH, the band intensity for condensed HA lowers at higher RH in deliquescence mode. The largest decrease was observed in $\mathrm{NaBr}$, and the smallest in NaI (not shown). In all salts, the particles retained liquid HA at RHs higher than their DRH. On the other

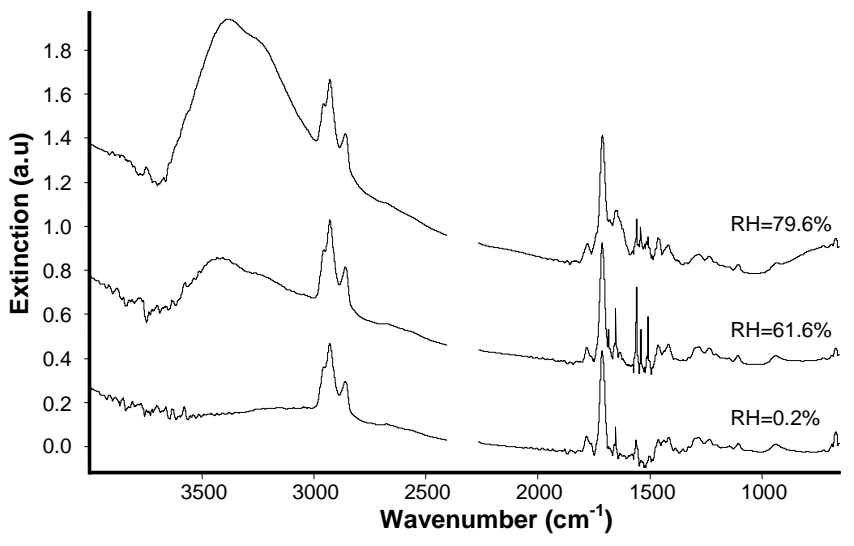

Figure 5. Infrared spectra of $\mathrm{NaBr}$ particles after passing through the heated reservoir containing OA and exposed to different RHs.

hand, the spectrum baseline in Fig. 6 deliquescence spectra also decreases at high wave number as RH increases (due to decrease of particle scattering), indicating a thinner coating of the particles.

The efflorescence behaviour of coated aqueous NaX particles was investigated by passing $\mathrm{NaX}$ aqueous particles along the heated oven containing the carboxylic acid vapour. For all the systems at RH near saturation, the spectra show bands of condensed phase organic acid. The intensity of these bands keeps roughly constant with $\mathrm{RH}$ in OA and LA, but liquid $\mathrm{HA}$ band intensities decrease notably as $\mathrm{RH}$ is reduced (a factor in the range 3-7 from $\mathrm{RH} \approx 100 \%$ to $27 \%$, depending on the salt). Figure 6 shows the case for $\mathrm{NaBr} / \mathrm{HA}$. Also the scattering signal is decreased with $\mathrm{RH}$, indicating that particles get smaller.

\subsubsection{Deliquescence and efflorescence curves}

Deliquescence and efflorescence curves were recorded by measuring the integrated absorbance of liquid water in the particles in the $3400-3600 \mathrm{~cm}^{-1}$ range and plotting the 

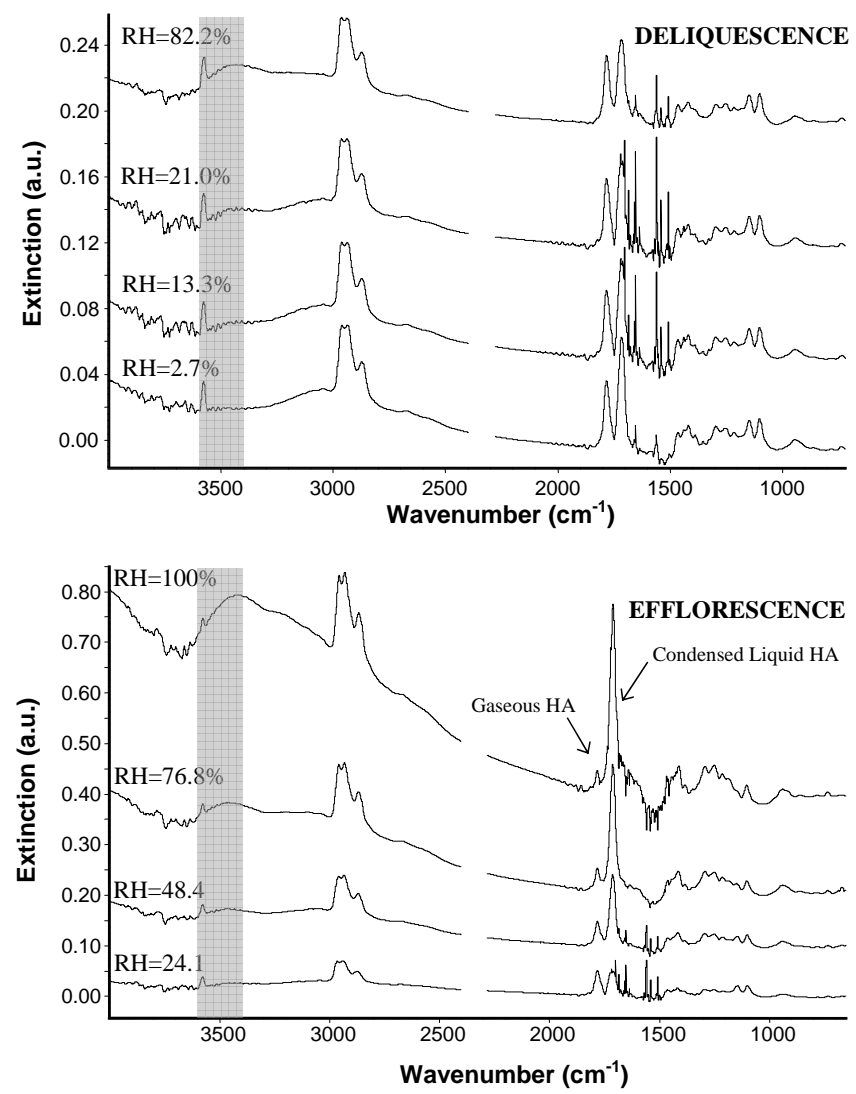

Figure 6. Spectra showing the evolution of the infrared absorption intensity of the $\mathrm{C}=\mathrm{O}$ band of hexanoic acid near $1700 \mathrm{~cm}^{-1}$ with $\mathrm{RH}$ in $\mathrm{NaBr}$ particles in deliquescence and efflorescence mode. Also the shaded region indicates the selected area for measuring liquid-water abundance in the particles (see text).

values versus RH. This interval was selected as it is mostly free of interference with nearby absorption spectral features. The scattering component of the liquid-water extinction spectrum was removed by subtracting the sloping baseline present at high wave numbers to obtain integrated absorbances. The results for all the systems are presented in Fig. 7. The curves for the pure inorganic salts have also been measured and are included in the figure. Hereafter, we describe the effect of the various acids in each of the inorganic salts as a function of RH with a special attention towards the deliquescence and efflorescence behaviour of the mixed particles.

1. $\mathrm{NaCl}$ particles. The deliquescence curve of $\mathrm{NaCl} / \mathrm{HA}$ follows the same trend to that of pure $\mathrm{NaCl}$ particles: no water uptake is detected until near $73 \% \mathrm{RH}$, where particles abruptly become liquid. Pure $\mathrm{NaCl}$ particles deliquesce at DRH $(298 \mathrm{~K})=75.3 \%$ (Tang and Munkelwitz, 1993), a similar value. However, SEM results show that particles uptake small amounts of water before sudden deliquescence (as evidenced by the particle curved edges in Fig. 4), although they are not enough to change their size. The quantity of liquid water taken up by $\mathrm{NaCl}$ particles is unaffected by the presence of the HA surfactant. However, for $\mathrm{NaCl} / \mathrm{OA}$ and $\mathrm{NaCl} / \mathrm{LA}$, particle deliquescence occurs near to $56 \% \mathrm{RH}$, substantially lower than the value corresponding to pure $\mathrm{NaCl}$. These results are in agreement with previous reports in which a DRH of $70 \%$ was observed for $\mathrm{NaCl}$ particles covered with OA and LA acids (Hansson et al., 1998). In $\mathrm{NaCl} / \mathrm{OA}$, the particles uptake larger amounts of water vapour than in pure $\mathrm{NaCl}$, whereas the opposite is observed for $\mathrm{NaCl} / \mathrm{LA}$.

The efflorescence curves for all the three acids locate the ERH close to $40 \%$. That value is in agreement with previous works using the same technique (Cziczo and Abbatt, 2000; Weis and Ewing, 1999) that located the ERH of pure $\mathrm{NaCl}$ particles at $40 \pm 5 \% \mathrm{RH}$. The curves are coincident in the $\mathrm{RH}=20-60 \%$ range, but diverge towards higher RHs. For all acids particles retain larger amounts of water than pure $\mathrm{NaCl}$ in the $\mathrm{RH}=60-95 \%$, the quantities being in the order LA $>\mathrm{OA}>\mathrm{HA}$. Also the amount of HA and OA in the particles decreases as liquid water is removed from them until the ERH is reached, whereas no change in the amount of LA is observed with RH.

2. $\mathrm{NaBr}$ particles. According to Fig. 7 data, $\mathrm{NaBr} / \mathrm{HA}$ particles deliquesce at somewhat higher $\mathrm{RH}$ than pure $\mathrm{NaBr}$ particles: liquid water in $\mathrm{NaBr} / \mathrm{HA}$ particles is not detected until $50 \% \mathrm{RH}$. This value does not change with the degree of coating, and contrasts with the value of $\mathrm{DRH}=37 \%$ for pure $\mathrm{NaBr}$ particles (Minambres et al., 2008). On the other hand, OA and LA as surfactants do not have any effect on the deliquescence behaviour of $\mathrm{NaBr}$. The deliquescence curves are practically coincident with those of pure $\mathrm{NaBr}$. Also, the amount of water taken up is similar to pure $\mathrm{NaBr}$, except for OAcovered particles, that uptake larger amounts of water for $\mathrm{RH}>70 \%$. Efflorescence curves for all acid surfactants are very similar to pure $\mathrm{NaBr}(\mathrm{ERH}=23 \%)$ in the 20-60\% RH (although OA retains slightly more water at all RHs), but at RH $>60 \%$ acid-covered particles retain higher amounts of liquid water than pure $\mathrm{NaBr}$ (up to double for $\mathrm{NaBr} / \mathrm{LA}$ at $90 \% \mathrm{RH}$ ). Thus the presence of the organic covering causes water loss to happen more gradually than in the pure salt at high RHs.

3. NaI particles. The deliquescence curves of acid-covered $\mathrm{NaI}$ particles exhibit substantial differences with respect to the pure salt. Whereas pure NaI particles take up water at all RHs (Minambres et al., 2011), NaI/HA and $\mathrm{NaI} / \mathrm{LA}$ particles do not uptake water until $\mathrm{RH}=16$ and $21 \%$, respectively. Liquid water is not detected in $\mathrm{NaI} / \mathrm{OA}$ particles until $\mathrm{RH}=75 \%$. It can be concluded that organic acid surfactant substantially retards the uptake of water in $\mathrm{NaI}$ particles, especially $\mathrm{OA}$ 
DELIQUESCENCE
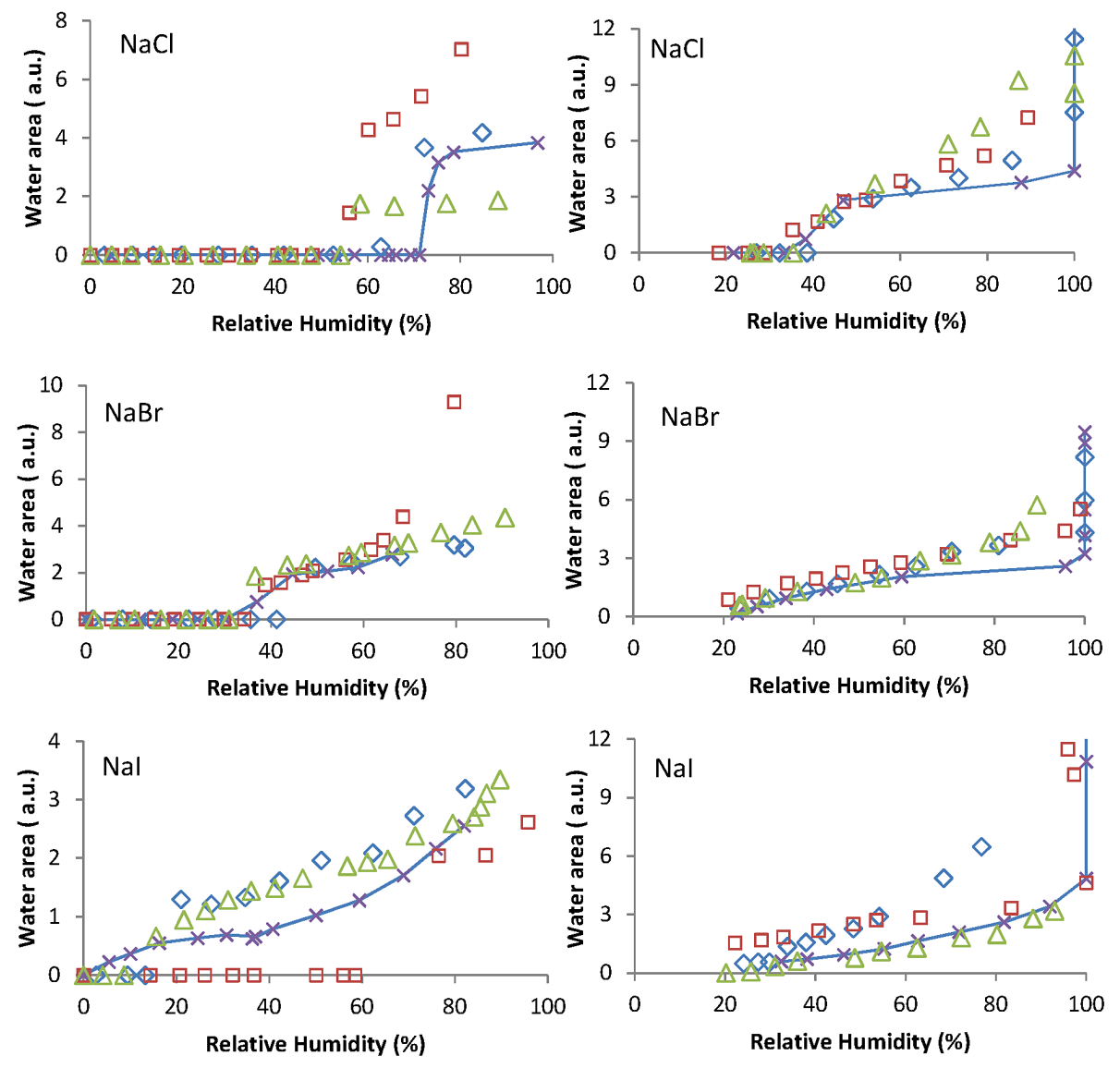

$\diamond$ Hexanoic Acid

口 Octanoic Acid

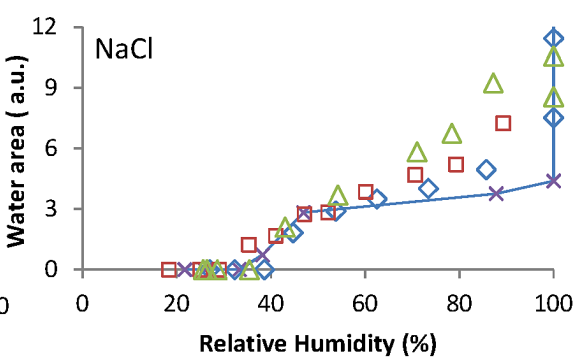

$\Delta$ Lauric Acid $\quad \longrightarrow$ Pure NaX

Figure 7. Deliquescence and efflorescence curves of $\mathrm{NaX}(\mathrm{X}=\mathrm{Cl}, \mathrm{Br}, \mathrm{I})$ particles covered with $\mathrm{HA}$, OA and LA. The curves for the pure inorganic salts are shown by lines. Left and right panels show deliquescence and efflorescence curves, respectively. Liquid-water mass is calculated as explained in Sect. 2 .

The amount of liquid water in HA and LA-covered particles in the $\mathrm{RH}=20-80 \%$ is higher than in pure $\mathrm{NaI}$. The efflorescence curve of NaI/LA is practically coincident with the pure $\mathrm{NaI}$ curve in the $\mathrm{RH}$ range measured. However, the HA-covered particles lose water more gradually, retaining higher amounts of water than pure $\mathrm{NaI}$ in the $\mathrm{RH}=30-80 \%$ range. Finally, OAcovered particles follow closely the pure salt curve for $\mathrm{RH}>80 \%$, but retain more water at lower RHs. The general tendency is that the presence of acid surfactant retains more water in the particles, except for LA, which shows little effect.

\subsubsection{Discussion of deliquescence and efflorescence processes}

The obtained results on the hygroscopicity of sodium halide particles covered with organic acids having low water solubility show an overall complex behaviour. The deliquescence curves of Fig. 7 indicate that the water uptake process is dependent on both the properties of inorganic salts and those of the organic acids. Although the effect of the acids on the water uptake of $\mathrm{NaBr}$ particles is small, in case of $\mathrm{NaCl}$ particles they produce a lowering of the DRH with respect to pure salt particles. On the contrary, in NaI these acids prevent particles to uptake liquid water at low RHs, unlike in pure NaI, which admits water condensation at RH as low as $6 \%$. This retarding effect is especially attributed to OA. In efflorescence a coherent behaviour is observed for all systems. The presence of the organic acid makes the particle to retain more water at a given RH, all curves converging at the ERH.

The observed hygroscopic behaviour can be due to several factors. The morphology of particles can sometimes influence their hygroscopic behaviour. However, all $\mathrm{NaX}$ solids have an octahedral crystal structure, so all $\mathrm{NaX}$ dry particles are expected to be cubic. This has been verified for $\mathrm{NaCl}$ particles by their SEM images in Fig. 4. Thus we do not expect a 
dependence of particle morphology in the hygroscopicity of different $\mathrm{NaX}$ salts. Another possibility is that each organic acid interacts differently with each inorganic salt. Organic acids in the surface of inorganic salts will tend to orientate their polar groups facing the salt surface so that ion-dipole interactions will arise that will diminish the system's Gibbs free energy. The polarizability of the halogen atoms increases in the order $\mathrm{Cl}(14.7)<\mathrm{Br}(21.8)<\mathrm{I}$ (35.1, all in atomic units) (Lide, 1994), so differences in the interaction magnitude are expected. In addition, the surface of particles will become more populated by anions as halide polarizability increases (Jungwirth and Tobias, 2001). Our measurements show that, for the same acid, the DRH increases with the polarizability of the halide anion. This behaviour also reflects the trend for pure $\mathrm{NaX}$ particles. The acid carbon chain length may also influence hygroscopic behaviour. In $\mathrm{NaCl}$ and $\mathrm{NaBr}$, a longer chain produces a decrease in the DRH for the HA-OA sequence ( $17 \%$ in $\mathrm{NaCl}, 13 \%$ in $\mathrm{NaBr}$ ). However, further increase in the chain length (LA) does not produce any effect in the DRH. On the other hand, in NaI the previous tendency does not take place, and there is a noticeable increase in DRH for OA. Other effects may be responsible for this behaviour. It has been proposed that the structure of the monolayers formed with insoluble surfactants determines their resistance towards gas uptake (Stemmler et al., 2008). Fatty acids form a highly ordered film in the so-called liquid condensed state, whereas in the liquid expanded state they form a less ordered film and do not hinder the uptake. In that way the differences in retardation in water uptake can arise from the different degrees of compression of such films (Donaldson and Vaida, 2006; Takahama and Russell, 2011). This can be one of the reasons for the observed behaviour in NaI / OA particles, although we cannot verify it experimentally. Another possibility is that gaseous water transport occurs through open sections of the surface that can be due to incomplete packing by the organic film or to random fluctuations (Donaldson and Vaida, 2006). SEM images of $\mathrm{NaCl} / \mathrm{LA}$ do not reveal any open section in the surface, although we cannot provide data for the rest of the acids. The observed salt-specific behaviour is in accordance with the observed deliquescent behaviour of internally mixed particles formed of sodium halide and water soluble organic acids (Minambres et al., 2011).

The hygroscopic behaviour can be correlated with the spectral features of the organic acids shown in Table 2, where the wave number and the bandwidth of the $\mathrm{C}=\mathrm{O}$ band in different environments are shown. The band-centre wave numbers shift in the $-6 /+10 \mathrm{~cm}^{-1}$ range in the presence of $\mathrm{NaX}$ salts. The bandwidth (FWHM) of the $\mathrm{C}=\mathrm{O}$ vibration for the bulk acids is in the $20-29 \mathrm{~cm}^{-1}$ range, but changes substantially for heterogeneously nucleated particles, that span the $13-62 \mathrm{~cm}^{-1}$ range (Table 2). For bulk HA, the $\mathrm{C}=\mathrm{O}$ bandwidth is $20 \mathrm{~cm}^{-1}$, but increases in NaX particles, ranging from 27 to $40 \mathrm{~cm}^{-1}$. In OA (FWHM of bulk acid is $\left.26 \mathrm{~cm}^{-1}\right)$, the bandwidth can either decrease $\left(13 \mathrm{~cm}^{-1}\right.$ in $\mathrm{NaCl} / \mathrm{OA})$ or increase $\left(36 \mathrm{~cm}^{-1}\right.$ in $\left.\mathrm{NaI} / \mathrm{OA}\right)$. Finally, the
FWHM of NaX/LA particles lies in the $19-26 \mathrm{~cm}^{-1}$ range, taking smaller values than in bulk LA $\left(29 \mathrm{~cm}^{-1}\right)$. The wavenumber shift and broadening of a spectral band may arise from a change in the internal force constant of the $\mathrm{C}=\mathrm{O}$ bond due to the formation of intermolecular bonds with other molecules, for example hydrogen bonds with water (Kalsi, 2007). These results are indicative of the effect of the ionic salt environment near organic acid molecules.

Although it is not easy to establish clear correlations with the changes in deliquescence behaviour, some remarks can be outlined. For systems with $\mathrm{NaBr}$ the changes in the FWHM of the $\mathrm{C}=\mathrm{O}$ band are the smallest (except for $\mathrm{HA} / \mathrm{NaBr}$ ), which correlate with no change in DRH, except for $\mathrm{HA} / \mathrm{NaBr}$ particles, that deliquesce at $13 \% \mathrm{RH}$ higher than in pure $\mathrm{NaBr}$. For $\mathrm{NaI}$ mixed with an organic acid, the changes in FWHM are considerable, ranging from $-16 \mathrm{~cm}^{-1}$ in LA to $+13 \mathrm{~cm}^{-1}$ in HA (Table 2). This indicates strong ion-polar head group interaction. However, the explanation for the water uptake behaviour in this case can be attributed to the hydrophobic effect exerted by the organic acids. It forms a barrier that prevents the entrance of gaseous water molecules inside the particles. This effect is very pronounced for $\mathrm{NaI} / \mathrm{OA}$, and we have not found a satisfactory explanation for it. Finally, in $\mathrm{NaCl} /$ organic acid systems, the opposite effect is observed, in which the presence of acids slightly enhance condensation of water. This can be attributed to the ion-polar group interaction that slightly lowers the Gibbs free energy of the system, favouring the uptake of gaseous water molecules. The efflorescence process in $\mathrm{NaX}$ aqueous particles is not substantially affected by the presence of the acid. As there is not an energy barrier in the efflorescence process (in contrast to deliquescence), water loss takes place gradually as RH is lowered. Additionally, the salting out effect of $\mathrm{NaCl}$ will make dissolved organic acid molecules (specially the most water soluble HA) gradually move to the surface as the concentration of the salt solution increases (Demou and Donaldson, 2002), and will be eventually removed from the surface together with water. However, as the magnitude of the salting out effect for HA is rather small (Demou and Donaldson, 2002), this effect is expected to contribute little in HA.

The results on water uptake and release, together with the release of HA from particles (exemplified in Fig. 6 for $\mathrm{NaBr}$ ) give information on how the dynamics of water exchange in inorganic particles is affected by the presence of a surface layer having low water solubility. In all deliquescence curves in Fig. 7, there is a competition for surface positions between adsorbed HA and gaseous water, as indicated by the evolution of the amounts of liquid HA and water with RH (or, equivalently, the relative amount of gaseous water) in Fig. 6. This can be reasoned as follows: in the deliquescence spectrum of Fig. 6, the amount of liquid HA decreases as RH (and consequently the amount of gaseous water) increases, indicating that, if we start from a dry crystalline $\mathrm{NaX}$ particle covered with HA, gaseous water tends 
to displace HA molecules away from the particle surface, to try to accommodate themselves on the $\mathrm{NaX}$ solid surface. This effect can be explained as a consequence of the change in the Gibbs free energy of the system in the deliquescence process: as the energetically most stable system is obtained when gaseous water molecules remain near the solid NaX surface (producing deliquescence when the number of gaseous water molecules reaches a given value), HA molecules will tend to be displaced from their surface locations. In efflorescence, however, the observed behaviour is different: removal of liquid water from aqueous particles having an organic HA coating due to the decrease of $\mathrm{RH}$ is accompanied by removal of HA from the particle surface. This effect can be explained assuming that liquid HA uniformly covers the $\mathrm{NaX}$ aqueous particle. Water molecules exiting the particles can interact with HA molecules in their surface locations and sweep them away. NaX-gaseous water interactions must be stronger in $\mathrm{NaCl}$ than in $\mathrm{NaBr}$ and $\mathrm{NaI}$ or, alternatively, $\mathrm{NaX}-\mathrm{HA}$ interactions will be weaker for $\mathrm{NaCl}$ than for $\mathrm{NaBr}$ and $\mathrm{NaI}$. For that reason, in $\mathrm{NaX} / \mathrm{HA}$ particles, HA is displaced more effectively from the surface at the DRH of pure $\mathrm{NaCl}$. In $\mathrm{NaBr}$ and $\mathrm{NaI}$, however, the number density of gaseous water molecules nearby the particles at the DRH of the pure inorganic particle is not enough to remove the HA cover, and a higher number of gaseous water molecules (higher $\mathrm{RH}$ ) is needed to produce particle deliquescence.

\subsection{Estimation of the relative amounts of organic acid and water in the particles}

The organic acid/liquid-water mole ratio in the NaX particles can be obtained by applying the Beer-Lambert law (as outlined in Sect. 2) if $\bar{A}_{i}$ and $\bar{\sigma}_{i}$ are known. For samples measured in the same aerosol cell, $N_{\text {org }} / N_{\mathrm{H}_{2} \mathrm{O}}=$ $\bar{A}_{\text {org }} \bar{\sigma}_{\mathrm{H}_{2} \mathrm{O}} / \bar{A}_{\mathrm{H}_{2} \mathrm{O}} \bar{\sigma}_{\text {org }}$. The absorption cross section of liquid water has been obtained from pure water data in the 2800$3600 \mathrm{~cm}^{-1}$ range (Downing and Williams, 1975), $\bar{\sigma}_{\mathrm{H}_{2} \mathrm{O}}=$ $1.3 \times 10^{-18} \mathrm{~m} \mathrm{molecule}^{-1}$. The absorption cross sections for liquid HA and OA have been obtained by measuring the integrated absorbance of a solution of the acid in methanol of known composition in a $150 \mu \mathrm{m}$ long cell for liquid samples. The $\mathrm{C}=\mathrm{O}$ band in the $1668-1774 \mathrm{~cm}^{-1}$ range was chosen to compute the integrated absorbance. The obtained values are $\bar{\sigma}_{\mathrm{HA}}=9.87 \times 10^{-19} \mathrm{mmolecule}^{-1}$ and $\bar{\sigma}_{\mathrm{OA}}=$ $1.71 \times 10^{-19} \mathrm{~m}$ molecule ${ }^{-1}$. From these data, the average $N_{\mathrm{HA}} / N_{\mathrm{H}_{2} \mathrm{O}}$ and $N_{\mathrm{OA}} / N_{\mathrm{H}_{2} \mathrm{O}}$ ratios have been calculated for the various salts at several RHs. The results appear in Fig. 8. The obtained results indicate that $N_{\mathrm{HA}} / N_{\mathrm{H}_{2} \mathrm{O}}$ values are comprised in the $0.1-0.6$ range for RH in the $30-98 \%$ interval, the lowest values corresponding to the highest RHs. In contrast, the $N_{\mathrm{OA}} / N_{\mathrm{H}_{2} \mathrm{O}}$ quotient spans from 0.2 to 1.9 (for RHs in the 40-96\% range), when again the highest values correspond to the lowest RH conditions. The highest $N_{\mathrm{OA}} / N_{\mathrm{H}_{2} \mathrm{O}}$ ratio (1.9) is obtained for NaI efflorescing par-

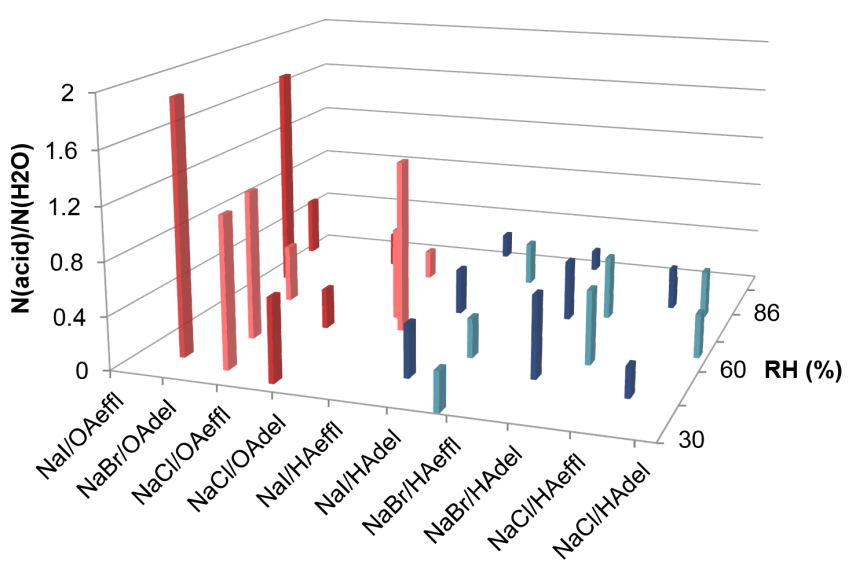

Figure 8. $N_{\mathrm{HA}} / N_{\mathrm{H}_{2} \mathrm{O}}$ and $N_{\mathrm{OA}} / N_{\mathrm{H}_{2} \mathrm{O}}$ mole ratios in heterogeneously coated particles at various relative humidities in deliquescence and efflorescence conditions. "del" and "effl" stand for deliquescence and efflorescence. "RH" stands for relative humidity.

ticles. The results in Fig. 8 indicate that, in general, OAcovered particles tend to displace liquid water more efficiently than HA-covered particles.

The spectroscopic results indicate that gaseous HA, OA and LA easily nucleate onto dry and aqueous $\mathrm{NaX}$ particles. The amount of acid taken up increases with the temperature of the oven. Additionally, SEM images of $\mathrm{NaCl}$ particles with $\mathrm{LA}$ show $\mathrm{NaCl}$ particle aggregates, indicating that they are "glued" by lauric acid. However, SEM images provide no visual evidence of the presence of an organic surfactant, so we can conclude that the cover must be much thinner than the size of the salt particles. Although in principle it is possible that part of the surfactant evaporates before particles are covered with gold, LA has a low vapour pressure $\left(2.2 \times 10^{-5} \mathrm{mbar}\right.$, see Table 1$)$, so we do not expect acid evaporation to alter the sample appreciably. A rough higher limit for the cover thickness can be set at $20 \mathrm{~nm}$, which is the resolution of the SEM images. This estimate can be compared with HA and OA cover thickness on aqueous particles, calculated assuming that liquid $\mathrm{HA}$ or OA arrange in a hydrophobic organic layer in the surface of an aqueous particle, according to one proposed model (Ellison et al., 1999), and taking into account the spectrally measured relative proportions of water and organic acid. The volume of a spherical aqueous particle of radius $R$ will be $V_{\mathrm{H}_{2} \mathrm{O}}=(4 / 3) \pi R^{3}$, whereas the volume of liquid organic coating of thickness $r$, assuming uniform coverage, can be written as $V_{\text {org }}=(4 / 3) \pi\left[(R+r)^{3}-R^{3}\right]$. On the other hand, $V_{\text {org }} / V_{\mathrm{H}_{2} \mathrm{O}}=N_{\text {org }} \rho_{\mathrm{H}_{2} \mathrm{O}} /\left(N_{\mathrm{H}_{2} \mathrm{O}} \rho_{\text {org }}\right)$, where $\rho$ stands for density. As the $N_{\mathrm{org}} / N_{\mathrm{H}_{2} \mathrm{O}}$ ratios have been determined previously, from the previous equations we can obtain $r$ in terms of the aqueous particle radius $R$ :

$r / R=\left[1+N_{\text {org }} \rho_{\mathrm{H}_{2} \mathrm{O}} /\left(N_{\mathrm{H}_{2} \mathrm{O}} \rho_{\text {org }}\right)\right]^{1 / 3}-1$. 
For typical values of $N_{\mathrm{HA}} / N_{\mathrm{H}_{2} \mathrm{O}}=0.1,0.3$ and $0.6, r / R=$ $0.035,0.098$ and 0.181 , respectively, indicating that the thickness of the organic layer increases roughly linearly with the number of molecules of liquid HA. For example, if $N_{\mathrm{HA}} / N_{\mathrm{H}_{2} \mathrm{O}}=0.3$ and $R=0.3 \mu \mathrm{m}$ (roughly corresponding to $\mathrm{NaCl}$ particles appearing in Fig. 4c), the HA coating thickness yields an estimation of $r=29 \mathrm{~nm}$ for a particle coated with HA. This value can be compared with the upper limit of $20 \mathrm{~nm}$ estimated for the cover thickness in the $\mathrm{LA} / \mathrm{NaCl}$ system. The former HA-coating thickness is much larger than the estimated thickness of a monolayer, which is roughly $0.3 \mathrm{~nm}$, assuming a completely extended linear chain and taking into account an average $\mathrm{C}-\mathrm{C}$ bond length of $0.077 \mathrm{~nm}$. However, we cannot affirm whether the particles are uniformly covered. Previous investigations indicate that the degree of insoluble acid coverage do not substantially alter DRH. Complete coverage of inorganic particles by fatty acids had no dramatic effect on $\mathrm{NaCl}$ particle DRH (Andrews and Larson, 1993). On the other hand, DRH of ammonium sulfate was only slightly lowered for oleic acid thickness up to $109 \mathrm{~nm}$ (Najera and Horn, 2009), much bigger than our estimated thickness of around $30 \mathrm{~nm}$. No variations in DRH with acid covering thickness were observed in this work.

\section{Conclusions and atmospheric implications}

This work studied the effect of a surfactant layer of hexanoic, octanoic and lauric acid, which are present in the Earth's troposphere, on the hygroscopic properties of sodium halide sub-micrometre particles, which are constituents of sea salt aerosol. Infrared extinction spectroscopy together with particle counting and visualizing techniques allowed us to detect the formation of homogeneously and heterogeneously nucleated particles and the variation of their composition in the presence of variable amounts of gaseous water, leading to the processes of deliquescence and efflorescence.

It was found that the hygroscopic properties of sodium halide particles covered with hexanoic, octanoic or lauric acid change both with the nature of the inorganic salt and the carboxylic acid. The DRH of $\mathrm{NaCl}$ aerosol experiences a moderate shift with the nature of the organic acid covering the particles. The deliquescence of $\mathrm{NaCl} / \mathrm{OA}$ and $\mathrm{NaCl} / \mathrm{LA}$ systems occurs near $\mathrm{RH}=56 \%$, below the DRH of pure $\mathrm{NaCl}$. On the other hand, $\mathrm{NaBr}$ covered particles do not substantially alter their water uptake behaviour respect to pure salt particles for OA and LA surfactants, but the DRH of $\mathrm{NaBr} / \mathrm{HA}$ particles is about $13 \%$ higher than that of pure $\mathrm{NaBr}$. Finally, organic acid covering on solid $\mathrm{NaI}$ particles acts as a barrier to water uptake; NaI particles deliquesce near 16 and $21 \%$ RH when coated with hexanoic and lauric acid, respectively, but the $\mathrm{DRH}$ of $\mathrm{NaI} / \mathrm{OA}$ particles rises to a value higher than $60 \%$. The general consequence is that the water uptake behaviour of sodium halide particles coated with organic acids is dependent on the nature of the anion and the carboxylic acid. This is in accordance with former studies of sodium halides with succinic acid, which showed a saltspecific behaviour. Consequently, although it is customary to extrapolate the water uptake behaviour of $\mathrm{NaCl}$ particles to sea salt aerosol due to the predominance of this species in marine salt, the detailed picture can be more complex.

Regarding efflorescence process, the obtained results indicated that the overall effect of the organic acid cover is to retain higher amounts of water at $\mathrm{RH}$ in the $60-90 \%$ range with respect to pure $\mathrm{NaX}$ particles. In $\mathrm{NaCl}$ particles the longer chain acid (LA) achieved the highest water retention, while the shortest one (HA) provided the lowest. All acids act similarly in $\mathrm{NaBr}$ aqueous particles, whereas in aqueous $\mathrm{NaI}$ particles OA is the acid that produces higher water retention at RH in the 60-90\% range. The results showed that this barrier effect is dependent on the nature of the organic acid, and can have important consequences for the troposphere, as the organic species can determine the amount of liquid water in the particles and their phase at a given RH. Based on our data, there is no simple correlation between water uptake or crystallization processes in coated salt particles and the length of the carbonated chain in the carboxylic acid. The complex behaviour in hygroscopic properties in the different salts cannot be easily attributed to a single effect, and the results point to more specific ion-molecule interactions in the $\mathrm{NaX} /$ organic $\mathrm{acid} / \mathrm{H}_{2} \mathrm{O}$ systems or to the structure of the organic film on the particle.

SEM measurements and data deduced from the infrared absorbance spectra indicated that the covering thickness of the obtained salt particles is compatible with an average value of $30 \mathrm{~nm}$. SEM images showed that the effect of lauric acid on $\mathrm{NaCl}$ is to agglomerate salt particles, producing bigger effective particles. It was not possible to observe this effect with the other acids, due to experimental inconveniences.

Several consequences for the atmosphere can be driven from this study: as bromine and iodine ions tend to segregate to the surface of marine aerosol particles, and the effect of fatty acids on them can be different as compared to the more abundant $\mathrm{NaCl}$ species, this may influence the surface properties of the particles not usually taken into account in the models. At a given value of ambient relative humidity, sea salt particles may have an outer core in which $\mathrm{NaBr}$ and $\mathrm{NaI}$ are more abundant, and if an organic layer having a low water solubility is present, the interactions of the organic compound will predominantly take place with bromide and iodide ions. At given conditions of relative humidity in the atmosphere, liquid-water amounts and phase of sea-salt particle outer core may vary regard to the expected behaviour of pure $\mathrm{NaCl}$ particles. This has consequences in the heterogeneous processes taking place between particles and atmospheric gases, such as gas uptake and chemical reactivity. 
Acknowledgements. The authors are grateful to Ministerio de Ciencia e Innovación (Madrid) for grant-in-aids (CGL2011-22441 and Consolider CSD-2007-00013), to Gobierno Vasco/Eusko Jaurlaritza (Vitoria-Gasteiz) for a Consolidated Research Group grant (IT520-10), and UPV/EHU for UFI11/23, SEM facilities (SGI/IZO-SGIker) and general support. L. Miñambres thanks UPV/EHU for a postdoctoral research grant. We are grateful to Cristina Gutiérrez from UPV/EHU for the use of the butanol CPC.

Edited by: T. Petäjä

\section{References}

Abbatt, J., Broekhuizen, K., and Pradeep Kumar, P.: Cloud condensation nucleus activity of internally mixed ammonium sulfate/organic acid aerosol particles, Atmos. Environ., 39, 47674778, 2005.

Andreae, M. and Rosenfeld, D.: Aerosol-cloud-precipitation interactions, Part 1, The nature and sources of cloud-active aerosols, Earth-Sci. Rev., 89, 13-41, 2008.

Andrews, E. and Larson, S. M.: Effect of Surfactant Layers on the Size Changes of Aerosol-Particles as a Function of RelativeHumidity, Environ. Sci. Technol., 27, 857-865, 1993.

Ault, A. P., Moffet, R. C., Baltrusaitis, J., Collins, D. B., Ruppel, M. J., Cuadra-Rodriguez, L. A., Zhao, D., Guasco, T. L., Ebben, C. J., and Geiger, F. M.: Size-dependent changes in sea spray aerosol composition and properties with different seawater condition, Environ. Sci. Technol., 47, 5603-5612, 2013.

Baker, A. R.: Marine aerosol iodine chemistry: The importance of soluble organic iodine, Environ. Chem., 2, 295-298, 2005.

Bialek, J., Dall'Osto, M., Monahan, C., Beddows, D., and O'Dowd, C.: On the contribution of organics to the North East Atlantic aerosol number concentration, Environ. Res. Lett., 7, 044013, 7 pp., doi:10.1088/1748-9326/7/4/044013, 2012.

Carpenter, L. J.: Iodine in the marine boundary layer, Chem. Rev. 103, 4953-4962, 2003.

Carslaw, K. S., Boucher, O., Spracklen, D. V., Mann, G. W., Rae, J. G. L., Woodward, S., and Kulmala, M.: A review of natural aerosol interactions and feedbacks within the Earth system, Atmos. Chem. Phys., 10, 1701-1737, doi:10.5194/acp-10-17012010, 2010.

Cavalli, F., Facchini, M. C., Decesari, S., Mircea, M., Emblico, L., Fuzzi, S., Ceburnis, D., Yoon, Y. J., O’Dowd, C. D., Putaud, J. P., and Dell'Acqua, A.: Advances in characterization of size-resolved organic matter in marine aerosol over the North Atlantic, J. Geophys. Res. Atmos., 109, D24215, doi:10.1029/2004JD005137, 2004.

Chakraborty, P. and Zachariah, M. R.: Sticking coefficient and processing of water vapor on organic-coated nanoaerosols, J. Phys. Chem. A., 112, 966-972, 2008.

Chuang, P. Y.: Measurement of the timescale of hygroscopic growth for atmospheric aerosols, J. Geophys. Res. Atmos., 108, 4282, 1984-2012, 2003.

Ciobanu, V. G., Marcolli, C., Krieger, U. K., Weers, U., and Peter, T.: Liquid- liquid phase separation in mixed organic/inorganic aerosol particles, J. Phys. Chem. A., 113, 10966-10978, 2009.

Cwiertny, D. M., Young, M. A., and Grassian, V. H.: Chemistry and Photochemistry of Mineral Dust Aerosol*, Annu. Rev. Phys. Chem., 59, 27-51, 2008.
Cziczo, D. and Abbatt, J.: Infrared observations of the response of $\mathrm{NaCl}, \mathrm{MgCl}_{2}, \mathrm{NH}_{4} \mathrm{HSO}_{4}$, and $\mathrm{NH}_{4} \mathrm{NO}_{3}$ aerosols to changes in relative humidity from 298 to $238 \mathrm{~K}$, J. Phys. Chem. A., 104, 2038-2047, 2000.

Dall'Osto, M., Ceburnis, D., Martucci, G., Bialek, J., Dupuy, R., Jennings, S. G., Berresheim, H., Wenger, J., Healy, R., Facchini, M. C., Rinaldi, M., Giulianelli, L., Finessi, E., Worsnop, D., Ehn, M., Mikkilä, J., Kulmala, M., and O’Dowd, C. D.: Aerosol properties associated with air masses arriving into the North East Atlantic during the 2008 Mace Head EUCAARI intensive observing period: an overview, Atmos. Chem. Phys., 10, 8413-8435, doi:10.5194/acp-10-8413-2010, 2010.

Davies, J. F., Miles, R. E., Haddrell, A. E., and Reid, J. P.: Influence of organic films on the evaporation and condensation of water in aerosol, P. Natl. Acad. Sci., 110, 8807-8812, 2013.

Demou, E. and Donaldson, D. J.: Adsorption of atmospheric gases at the air-water interface. 4: The influence of salts, J. Phys. Chem. A., 106, 982-987, 2002.

Dennis-Smither, B. J., Hanford, K. L., Kwamena, N. A., Miles, R. E. H., and Reid, J. P.: Phase, Morphology, and Hygroscopicity of Mixed Oleic Acid/Sodium Chloride/Water Aerosol Particles before and after Ozonolysis, J. Phys. Chem. A., 116, 6159-6168, 2012.

Donaldson, D. J. and Vaida, V.: The influence of organic films at the air-aqueous boundary on atmospheric processes, Chem. Rev., 106, 1445-1461, 2006.

Downing, H. D. and Williams, D.: Optical constants of water in the infrared. J. Geophys. Res., 80, 1656-1661, 1975.

Duce, R., Mohnen, V., Zimmerman, P., Grosjean, D., Cautreels, W., Chatfield, R., Jaenicke, R., Ogren, J., Pellizzari, E., and Wallace, G.: Organic material in the global troposphere, Rev. Geophys., 21, 921-952, 1983.

Ebben, C. J., Ault, A. P., Ruppel, M. J., Ryder, O. S., Bertram, T. H., Grassian, V. H., Prather, K. A., and Geiger, F. M.: Size-Resolved Sea Spray Aerosol Particles Studied by Vibrational Sum Frequency Generation, J. Phys. Chem. A., 117, 6589-6601, 2013.

Ellison, G. B., Tuck, A. F., and Vaida, V.: Atmospheric processing of organic aerosols, J. Geophys. Res. Atmos. (1984-2012), 104, 11633-11641, 1999.

Fierz-Schmidhauser, R., Zieger, P., Vaishya, A., Monahan, C., Bialek, J., O’Dowd, C., Jennings, S., Baltensperger, U., and Weingartner, E.: Light scattering enhancement factors in the marine boundary layer (Mace Head, Ireland), J. Geophys. Res. Atmos. (1984-2012), 115, D20204, doi:10.1029/2009JD013755 2010.

Finlayson-Pitts, B. J.: Reactions at surfaces in the atmosphere: integration of experiments and theory as necessary (but not necessarily sufficient) for predicting the physical chemistry of aerosols, Phys. Chem. Chem. Phys., 11, 7760-7779, 2009.

Finlayson-Pitts, B. J.: The tropospheric chemistry of sea salt: A molecular-level view of the chemistry of $\mathrm{NaCl}$ and $\mathrm{NaBr}$, Chem. Rev., 103, 4801-4822, 2003.

Firanescu, G., Hermsdorf, D., Ueberschaer, R., and Signorell, R.: Large molecular aggregates: From atmospheric aerosols to drug nanoparticles, Phys. Chem. Chem. Phys., 8, 4149-4165, 2006.

Freney, E. J., Martin, S. T., and Buseck, P. R.: Deliquescence and efflorescence of potassium salts relevant to biomass-burning aerosol particles, Aerosol Sci. Technol., 43, 799-807, 2009. 
Frinak, E. K. and Abbatt, J. P. D.: $\mathrm{Br}^{2}$ production from the heterogeneous reaction of gas-phase $\mathrm{OH}$ with aqueous salt solutions: Impacts of acidity, halide concentration, and organic surfactants, J. Phys. Chem. A., 110, 10456-10464, 2006.

Gadermann, M., Preston, T. C., Troster, C., and Signorell, R.: Characterization of palmitic and lauric acid aerosols from rapid expansion of supercritical $\mathrm{CO}_{2}$ solutions, Mol. Phys., 106, 945953, 2008.

Gantt, B. and Meskhidze, N.: The physical and chemical characteristics of marine primary organic aerosol: a review, Atmos. Chem. Phys., 13, 3979-3996, doi:10.5194/acp-13-3979-2013, 2013.

Garland, R. M., Wise, M. E., Beaver, M. R., DeWitt, H. L., Aiken, A. C., Jimenez, J. L., and Tolbert, M. A.: Impact of palmitic acid coating on the water uptake and loss of ammonium sulfate particles, Atmos. Chem. Phys., 5, 1951-1961, doi:10.5194/acp-51951-2005, 2005.

Garland, E. R., Rosen, E. P., Clarke, L. I., and Baer, T.: Structure of submonolayer oleic acid coverages on inorganic aerosol particles: evidence of island formation, Phys. Chem. Chem. Phys., 10, 3156-3161, 2008.

Ghosal, S., Brown, M. A., Bluhm, H., Krisch, M. J., Salmeron, M., Jungwirth, P., and Hemminger, J. C.: Ion Partitioning at the Liquid/Vapor Interface of a Multicomponent Alkali Halide Solution: A Model for Aqueous Sea Salt Aerosols, J. Phys. Chem. A., 112, 12378-12384, 2008

Gill, P., Graedel, T., and Weschler, C.: Organic films on atmospheric aerosol particles, fog droplets, cloud droplets, raindrops, and snowflakes, Rev. Geophys., 21, 903-920, 1983.

Hämeri, K., Rood, M., and Hansson, H.: Hygroscopic properties of a $\mathrm{NaCl}$ aerosol coated with organic compounds, J. Aerosol Sci., 23, 437-440, 1992.

Hansson, H. C., Rood, M. J., Koloutsou-Vakakis, S., Hameri, K., Orsini, D., and Wiedensohler, A.: $\mathrm{NaCl}$ aerosol particle hygroscopicity dependence on mixing with organic compounds, J. Atmos. Chem., 31, 321-346, 1998.

Hayase, S., Yabushita, A., Kawasaki, M., Enami, S., Hoffmann, M. R., and Colussi, A. J.: Weak Acids Enhance Halogen Activation on Atmospheric Water's Surfaces, J. Phys. Chem. A., 115, 49354940, 2011.

Hinds, W. C.: Aerosol technology: properties, behavior, and measurement of airborne particle, 2nd Ed., John Wiley \& Sons, 1998.

Hunt, S. W., Roeselova, M., Wang, W., Wingen, L. M., Knipping, E. M., Tobias, D. J., Dabdub, D., and Finlayson-Pitts, B. J.: Formation of molecular bromine from the reaction of ozone with deliquesced $\mathrm{NaBr}$ aerosol: Evidence for interface chemistry, $\mathrm{J}$. Phys. Chem. A., 108, 11559-11572, 2004.

IPCC, Climate Change 2013: The Physical Science Basis, Contribution of Working Group I to the Fifth Assessment Report of the Intergovernmental Panel on Climate Change, in: Clouds and Aerosols, edited by: Stocker, T. F., Qin, D., Plattner, G.-K., Tignor, M., Allen, S. K., Boschung, J., Nauels, A., Xia, Y., Bex, V., and Midgley, P. M., Cambridge University Press, Cambridge, United Kingdom and New York, NY, USA, 571-658, 2013.

Jungwirth, P. and Tobias, D. J.: Molecular structure of salt solutions: a new view of the interface with implications for heterogeneous atmospheric chemistry, J. Phys. Chem. B., 105, 10468-10472, 2001

Kalsi, P.: Spectroscopy of organic compounds, , 6th Ed., New Age International, New Delhi, 2007.
Kleefeld, S., Hoffer, A., Krivacsy, Z., and Jennings, S.: Importance of organic and black carbon in atmospheric aerosols at Mace Head, on the west coast of Ireland $\left(5319^{\prime} \mathrm{N}, 954^{\prime} \mathrm{W}\right)$, Atmos. Environ., 36, 4479-4490, 2002.

Krueger, B. J., Grassian, V. H., Iedema, M. J., Cowin, J. P., and Laskin, A.: Probing heterogeneous chemistry of individual atmospheric particles using scanning electron microscopy and energydispersive X-ray analysis, Anal. Chem., 75, 5170-5179, 2003.

Kwamena, N.-A., Buajarern, J., and Reid, J. P.: Equilibrium Morphology of Mixed Organic/Inorganic/Aqueous Aerosol Droplets: Investigating the Effect of Relative Humidity and Surfactants, J. Phys. Chem. A., 114, 5787-5795, 2010.

Lewis, R. and Schwartz, E.: Sea salt aerosol production: mechanisms, methods, measurements and models - a critical review, American Geophysical Union, 2004.

Lide, D. R.: CRC handbook of chemistry and physics, CRC press, Boca Raton, FL, 6-64 to 98, 1994.

Limbeck, A. and Puxbaum, H.: Organic acids in continental background aerosols, Atmos. Environ., 33, 1847-1852, 1999.

Ma, X., Chakraborty, P., Henz, B. J., and Zachariah, M. R.: Molecular dynamic simulation of dicarboxylic acid coated aqueous aerosol: structure and processing of water vapor, Phys. Chem. Chem. Phys., 13, 9374-9384, 2011.

Martin, S. T.: Phase transitions of aqueous atmospheric particles, Chem. Rev., 100, 3403-3453, 2000.

Metzger, S. and Lelieveld, J.: Reformulating atmospheric aerosol thermodynamics and hygroscopic growth into fog, haze and clouds, Atmos. Chem. Phys., 7, 3163-3193, doi:10.5194/acp-73163-2007, 2007.

Middlebrook, A. M., Murphy, D. M., and Thomson, D. S.: Observations of organic material in individual marine particles at Cape Grim during the First Aerosol Characterization Experiment (ACE 1), J. Geophys. Res., 103, 16475-16483, 1998.

Mikhailov, E., Vlasenko, S., Rose, D., and Pöschl, U.: Mass-based hygroscopicity parameter interaction model and measurement of atmospheric aerosol water uptake, Atmos. Chem. Phys., 13, $717-$ 740, doi:10.5194/acp-13-717-2013, 2013.

Minambres, L., Sanchez, M. N., Castano, F., and Basterretxea, F. J.: Infrared spectroscopic properties of sodium bromide aerosols, J. Phys. Chem. A., 112, 6601-6608, 2008.

Minambres, L., Sanchez, M. N., Castano, F., and Basterretxea, F. J.: Hygroscopic Properties of Internally Mixed Particles of Ammonium Sulfate and Succinic Acid Studied by Infrared Spectroscopy, J. Phys. Chem. A., 114, 6124-6130, 2010.

Minambres, L., Mendez, E., Sanchez, M. N., Castano, F., and Basterretxea, F. J.: Water uptake properties of internally mixed sodium halide and succinic acid particles, Atmos. Environ., 45, 5896-5902, 2011.

Mochida, M., Kitamori, Y., Kawamura, K., Nojiri, Y., and Suzuki, K.: Fatty acids in the marine atmosphere: Factors governing their concentrations and evaluation of organic films on sea-salt particles, J. Geophys. Res. Atmos. (1984-2012), 107, 4325, doi:10.1029/2001JD001278, 2002.

Najera, J. J. and Horn, A. B.: Infrared spectroscopic study of the effect of oleic acid on the deliquescence behaviour of ammonium sulfate aerosol particles, Phys. Chem. Chem. Phys., 11, 483-494, 2009. 
O’Dowd, C. D. and De Leeuw, G.: Marine aerosol production: a review of the current knowledge, Philos. Trans. R. Soc. London, Ser. A., 365, 1753-1774, 2007.

O'Dowd, C. D., Smith, M. H., Consterdine, I. E., and Lowe, J. A.: Marine aerosol, sea-salt, and the marine sulphur cycle: A short review, Atmos. Environ., 31, 73-80, 1997.

O’Dowd, C. D., Jimenez, J. L., Bahreini, R., Flagan, R. C., Seinfeld, J. H., Hämeri, K., Pirjola, L., Kulmala, M., Jennings, S. G., and Hoffmann, T.: Marine aerosol formation from biogenic iodine emissions, Nature, 417, 632-636, 2002.

O’Dowd, C. D., Facchini, M. C., Cavalli, F., Ceburnis, D., Mircea, M., Decesari, S., Fuzzi, S., Yoon, Y. J., and Putaud, J.: Biogenically driven organic contribution to marine aerosol, Nature, 431, 676-680, 2004.

Ovadnevaite, J., Ceburnis, D., Martucci, G., Bialek, J., Monahan, C., Rinaldi, M., Facchini, M. C., Berresheim, H., Worsnop, D. R., and O'Dowd, C. Primary marine organic aerosol: A dichotomy of low hygroscopicity and high CCN activity, Geophys. Res. Lett., 38, L21806, doi:10.1029/2011GL048869, 2011a.

Ovadnevaite, J., O'Dowd, C., Dall'Osto, M., Ceburnis, D., Worsnop, D. R., and Berresheim, H.: Detecting high contributions of primary organic matter to marine aerosol: A case study, Geophys. Res. Lett., 38, L02807, doi:10.1029/2010GL046083, 2011b.

Prather, K. A., Bertram, T. H., Grassian, V. H., Deane, G. B., Stokes, M. D., DeMott, P. J., Aluwihare, L. I., Palenik, B. P., Azam, F., and Seinfeld, J. H.: Bringing the ocean into the laboratory to probe the chemical complexity of sea spray aerosol, P. Natl. Acad. Sci., 110, 7550-7555, 2013.

Putaud, J., Van Dingenen, R., Mangoni, M., Virkkula, A., Raes, F., Maring, H., Prospero, J., Swietlicki, E., Berg, O., and Hillamo, R.: Chemical mass closure and assessment of the origin of the submicron aerosol in the marine boundary layer and the free troposphere at Tenerife during ACE-2, Tellus Ser. B., 52, 141-168, 2000.

Quinn, P. and Bates, T.: The case against climate regulation via oceanic phytoplankton sulphur emissions, Nature, 480, 51-56, 2011.

Read, K. A., Mahajan, A. S., Carpenter, L. J., Evans, M. J., Faria, B. V., Heard, D. E., Hopkins, J. R., Lee, J. D., Moller, S. J., and Lewis, A. C.: Extensive halogen-mediated ozone destruction over the tropical Atlantic Ocean, Nature, 453, 1232-1235, 2008.

Reid, J. P., Dennis-Smither, B. J., Kwamena, N. A., Miles, R. E., Hanford, K. L., and Homer, C. J.: The morphology of aerosol particles consisting of hydrophobic and hydrophilic phases: hydrocarbons, alcohols and fatty acids as the hydrophobic component, Phys. Chem. Chem. Phys., 13, 15559-15572, 2011.

Rinaldi, M., Decesari, S., Finessi, E., Giulianelli, L., Carbone, C., Fuzzi, S., O'Dowd, C. D., Ceburnis, D., and Facchini, M. C.: Primary and secondary organic marine aerosol and oceanic biological activity: Recent results and new perspectives for future studies, Adv. Meteor., 2010, 310682, doi:10.1155/2010/310682, 2010.

Robinson, C. B., Schill, G. P., Zarzana, K. J., and Tolbert, M. A.: Impact of Organic Coating on Optical Growth of Ammonium Sulfate Particles, Environ. Sci. Technol., 47, 13339-13346, 2013.

Rossi, M. J.: Heterogeneous reactions on salts, Chem. Rev., 103, 4823-4882, 2003.
Rouvière, A. and Ammann, M.: The effect of fatty acid surfactants on the uptake of ozone to aqueous halogenide particles, Atmos. Chem. Phys., 10, 11489-11500, doi:10.5194/acp-1011489-2010, 2010.

Rubasinghege, G., Ogden, S., Baltrusaitis, J., and Grassian, V. H.: Heterogeneous Uptake and Adsorption of Gas-Phase Formic Acid on Oxide and Clay Particle Surfaces: The Roles of Surface Hydroxyl Groups and Adsorbed Water in Formic Acid Adsorption and the Impact of Formic Acid Adsorption on Water Uptake, J. Phys. Chem. A., 117, 11316-11327, 2013.

Safar, M., Bertrand, D., Robert, P., Devaux, M., and Genot, C.: Characterization of edible oils, butters and margarines by Fourier transform infrared spectroscopy with attenuated total reflectance, J. Am. Oil Chem. Soc., 71, 371-377, 1994.

Saiz-Lopez, A., Plane, J. M. C., Mahajan, A. S., Anderson, P. S., Bauguitte, S. J.-B., Jones, A. E., Roscoe, H. K., Salmon, R. A., Bloss, W. J., Lee, J. D., and Heard, D. E.: On the vertical distribution of boundary layer halogens over coastal Antarctica: implications for $\mathrm{O}_{3}, \mathrm{HO}_{\mathrm{x}}, \mathrm{NO}_{\mathrm{x}}$ and the $\mathrm{Hg}$ lifetime, Atmos. Chem. Phys., 8, 887-900, doi:10.5194/acp-8-887-2008, 2008.

Samy, S., Mazzoleni, L. R., Mishra, S., Zielinska, B., and Hallar, A. G.: Water-soluble organic compounds at a mountain-top site in Colorado, USA, Atmos. Environ., 44, 1663-1671, 2010.

Schauer, J. J., Kleeman, M. J., Cass, G. R., and Simoneit, B. R.: Measurement of emissions from air pollution sources. 1. C1 through C29 organic compounds from meat charbroiling, Environ. Sci. Technol., 33, 1566-1577, 1999.

Schauer, J. J., Kleeman, M. J., Cass, G. R., and Simoneit, B. R.: Measurement of emissions from air pollution sources. 4. C1-C27 organic compounds from cooking with seed oils, Environ. Sci. Technol., 36, 567-575, 2002.

Soule, M. C. K., Blower, P. G., and Richmond, G. L.: Effects of atmospherically important solvated ions on organic acid adsorption at the surface of aqueous solutions, J. Phys. Chem. B., 111, 13703-13713, 2007.

Stemmler, K., Vlasenko, A., Guimbaud, C., and Ammann, M.: The effect of fatty acid surfactants on the uptake of nitric acid to deliquesced $\mathrm{NaCl}$ aerosol, Atmos. Chem. Phys., 8, 5127-5141, doi:10.5194/acp-8-5127-2008, 2008.

Sun, L., Li, X., Hede, T., Tu, Y., Leck, C., and Ågren, H.: Molecular dynamics simulations of the surface tension and structure of salt solutions and clusters, J. Phys. Chem. B., 116, 3198-3204, 2012.

Sun, L., Hede, T., Tu, Y., Leck, C., and Ågren, H.: Combined Effect of Glycine and Sea Salt on Aerosol Cloud Droplet Activation Predicted by Molecular Dynamics Simulations, J. Phys. Chem. A., 117, 10746-10752, 2013.

Tabazadeh, A.: Organic aggregate formation in aerosols and its impact on the physicochemical properties of atmospheric particles, Atmos. Environ., 39, 5472-5480, 2005.

Takahama, S. and Russell, L.: A molecular dynamics study of water mass accommodation on condensed phase water coated by fatty acid monolayers, J. Geophys. Res. Atmos., 116, D02203, doi:10.1029/2010JD014842, 2011.

Tang, I. N. and Munkelwitz, H. R.: Composition and TemperatureDependence of the Deliquescence Properties of Hygroscopic Aerosols, Atmos. Environ. Part A., 27, 467-473, 1993.

Tervahattu, H., Hartonen, K., Kerminen, V. M., Kupiainen, K., Aarnio, P., Koskentalo, T., Tuck, A. F., and Vaida, V.: New evi- 
dence of an organic layer on marine aerosols, J. Geophys. Res. Atmos., 107, 4053, doi:10.1029/2000JD000282, 2002.

Vaishya, A., Ovadnevaite, J., Bialek, J., Jennings, S. G., Ceburnis, D., and O'Dowd, C. D.: Bistable effect of organic enrichment on sea spray radiative properties, Geophys. Res. Lett., 40, 63956398, 2013.

Veghte, D. P., Altaf, M. B., and Freedman, M. A.: Size Dependence of the Structure of Organic Aerosol, J. Am. Chem. Soc., 135, 16046-16049, 2013.

Von Glasow, R.: Atmospheric chemistry - Sun, sea and ozone destruction, Nature, 453, 1195-1196, 2008.

Wagner, J., Andrews, E., and Larson, S. M.: Sorption of vapor phase octanoic acid onto deliquescent salt particles, J. Geophys. Res., 101, 19533-19540, 1996.

Weis, D. D. and Ewing, G. E.: Infrared spectroscopic signatures of $\left(\mathrm{NH}_{4}\right)_{2} \mathrm{SO}_{4}$ aerosols, J. Geophys. Res., 101, 18709-18720, 1996.
Weis, D. D. and Ewing, G. E.: Water content and morphology of sodium chloride aerosol particles, J. Geophys. Res. Atmos., 104, 21275-21285, 1999.

Wise, M. E., Baustian, K. J., Koop, T., Freedman, M. A., Jensen, E. J., and Tolbert, M. A.: Depositional ice nucleation onto crystalline hydrated $\mathrm{NaCl}$ particles: a new mechanism for ice formation in the troposphere, Atmos. Chem. Phys., 12, 1121-1134, doi:10.5194/acp-12-1121-2012, 2012.

Yassaa, N., Meklati, B. Y., Brancaleoni, E., Frattoni, M., and Ciccioli, P.: Polar and non-polar volatile organic compounds (VOCs) in urban Algiers and saharian sites of Algeria, Atmos. Environ., 35, 787-801, 2001.

Zangmeister, C. D., Turner, J. A., and Pemberton, J. E.: Segregation of $\mathrm{NaBr}$ in $\mathrm{NaBr} / \mathrm{NaCl}$ crystals grown from aqueous solutions: Implications for sea salt surface chemistry, Geophys. Res. Lett., 28, 995-998, 2001. 